\title{
Glass and Process Development for the Next Generation of Optical Fibers: A Review
}

\author{
John Ballato ${ }^{1}$, Heike Ebendorff-Heidepriem ${ }^{2}$, Jiangbo Zhao ${ }^{2}$, Laeticia Petit ${ }^{3, *}$ \\ and Johann Troles ${ }^{4}$ \\ 1 Department of Materials Science and Engineering and the Center for Optical Materials Science and \\ Engineering Technologies (COMSET), Clemson University, Clemson, SC 29364, USA; jballat@clemson.edu \\ 2 Institute for Photonics and Advanced Sensing, School of Physical Sciences and ARC Centre of Excellence for \\ Nanoscale BioPhotonics, The University of Adelaide, Adelaide 5005, Australia; \\ heike.ebendorff@adelaide.edu.au (H.E.-H.); tim.zhao@adelaide.edu.au (J.Z.) \\ 3 Laboratory of Photonics, Tampere University of Technology, Tampere FI-33101, Finland \\ 4 Glasses and Ceramics Group, Unité Mixte de Recherche, Centre National de la Recherche \\ Scientifique (UMR-CNRS) 6226, Institut des Sciences Chimiques de Rennes, University of Rennes 1, \\ 35042 Rennes, France; johann.troles@univ-rennes1.fr \\ * Correspondence: laeticia.petit@tut.fi; Tel.: +358-50-447-8481
}

Academic Editors: Giancarlo C. Righini, Shibin Jiang and Francesco Prudenzano

Received: 22 December 2016; Accepted: 22 February 2017; Published: 10 March 2017

\begin{abstract}
Applications involving optical fibers have grown considerably in recent years with intense levels of research having been focused on the development of not only new generations of optical fiber materials and designs, but also on new processes for their preparation. In this paper, we review the latest developments in advanced materials for optical fibers ranging from silica, to semi-conductors, to particle-containing glasses, to chalcogenides and also in process-related innovations.
\end{abstract}

Keywords: optical glasses; silica-based optical fibers; nanoparticle-doped glasses; semiconductor core optical fibers; chalcogenide optical fibers

\section{Introduction}

Because of their attributes (high reliability over long distances, low attenuation, low interference, high security, very high information capacity, longer life span and ease of maintenance), optical fibers have had a profound impact on telecommunication where they transport light pulses from one point to another. The first commercially-relevant fibers, made from silica $\left(\mathrm{SiO}_{2}\right)$ glass, were developed in the 1960s. Shortly thereafter, the first low loss optical fibers were realized [1].

A half-century after the development of the first optical fibers, enabled by the ubiquity of telecommunication-grade glass fibers, optical fibers have found numerous other applications in laser-based manufacturing (e.g., precision cutting, drilling and welding) [2], illumination, sensing and imaging, to cite just a few. Optical fibers also are well suited to biomedical applications. They can be used to view inside the body without having to perform surgery, as the optical fiber can be easily inserted-due to their small size and flexibility-into veins, arteries, lungs and other accessible parts of the body. They can be used as physical sensors of temperature, pressure and radiation; and also as chemical sensors of $\mathrm{pH}$, partial pressure of blood gases and glucose, as reviewed in [3]. Those many new applications have initiated a global search for new material- and process-oriented innovations, as the wavelength of the light used in the application dictates the selection of enabling materials and designs.

Presented here is an overview of the advanced materials and processing innovations employed for the preparation of next generation optical fibers. This overview is divided in five parts. The first section 
presents the recent progresses in the development of silica-based fibers. The latest developments in fibers with nanoparticles contained within the core and semiconductor core fibers are presented in Sections 3 and 4, respectively. Chalcogenide fibers for use at mid-IR wavelength are discussed in Section 5. Finally, future opportunities of the new generation of fibers are summarized in Section 6.

\section{Silica-Based Optical Fibers}

Rare-earth (RE)-doped fiber-based lasers are a very active area of present research and development due to their compactness, excellent beam quality and handling capability. Accordingly, the fabrication of new RE-doped fibers has attracted considerable attention with improvements in lasing performance being a prime motivation. Silica glass remains the main glass host for fiber lasers due to its excellent transparency, high mechanical strength and thermal robustness. Silica generally exhibits a low solubility for RE ions, which leads to RE clustering and a deterioration in spectroscopic properties. In order to lessen such clustering, the core region of the fiber is co-doped with alumina $\left(\mathrm{Al}_{2} \mathrm{O}_{3}\right)$ or phosphorus pentoxide $\left(\mathrm{P}_{2} \mathrm{O}_{5}\right)$ [4]. In order to reduce $\mathrm{RE}$ clustering, 8-10 $\mathrm{Al}$ or $15 \mathrm{P}$ atoms per $\mathrm{RE}$ ion should be added [5,6]. Co-doping silica glass with $\mathrm{Al}_{2} \mathrm{O}_{3}$ and $\mathrm{P}_{2} \mathrm{O}_{5}$ was found to lead to higher rare-earth doping levels than in binary $\mathrm{P}_{2} \mathrm{O}_{5}-\mathrm{SiO}_{2}$ or $\mathrm{Al}_{2} \mathrm{O}_{3}-\mathrm{SiO}_{2}$ glasses [7], prior to the onset of concentration quenching, and to the formation of $\mathrm{AlPO}_{4}$-type structural units, which actually leads to a glass with a lower refractive index (RI) than that of silica [8]. This codoping allows one to process glasses with large $\mathrm{P}_{2} \mathrm{O}_{5}$ and $\mathrm{Al}_{2} \mathrm{O}_{3}$ concentrations to further improve $\mathrm{RE}$ dissolution, while maintaining a practical refractive index. The focus here is to review different techniques used for the fabrication of silica fibers.

Rare-earth (RE)-doped fibers have often been fabricated using a combination of modified chemical vapor deposition (MCVD) and solution doping [9], given the simplicity and versatility of these processes in the manufacturing of single or low-moded fibers. Unfortunately, MCVD with solution doping is a multi-step procedure that produces a doped core made of 1-10 layers and, so, limits the accuracy and flexibility of dopant concentration and refractive index profiles (RIPs). Due to the low vapor pressure of RE halide precursors at room temperature, it is difficult to deposit rare-earth (RE) ions using conventional vapor delivery system, as is used for the main glass component precursors such as $\mathrm{SiCl}_{4}, \mathrm{GeCl}_{4}$, and $\mathrm{POCl}_{3}[10]$. Similar problems are encountered when adding $\mathrm{Al}_{2} \mathrm{O}_{3}$, which is used to decrease RE ion clustering as discussed above [11]. In order to overcome these issues, alternative methods to fabricate active optical silica fibers have been developed. A summary of recent advances in these techniques will now be discussed.

Though more challenging, methods for the gas phase doping of rare-earth ions using MCVD have been developed [12]. Silica preforms exhibiting uniform dopant concentrations in both radial and longitudinal directions have been successfully prepared with good reproducibility [13]. For example, a $\mathrm{Yb}$-doped silica fiber was prepared using this technique with a background loss at $25 \mathrm{~dB} \cdot \mathrm{km}^{-1}$ at $1200 \mathrm{~nm}$, which showed lasing up to $200 \mathrm{~W}$ with a slope efficiency of about $80 \%$ [14]. These results were similar to fibers fabricated using conventional MCVD/solution doping methods. Although preforms with a core diameter larger than $5 \mathrm{~mm}$ can be easily prepared, this modified MCVD technique has not been widely reported; most likely due to the fact that only commercially available high temperature gas delivery systems and chelate raw materials can be used, limiting the development of new glass compositions.

Other novel approaches to the fabrication of rare-earth-doped silica fibers are as follows. The Optoelectronics Research Centre (ORC) at the University of Southampton (Southampton, England) has pioneered an MCVD in-situ doping technique and the "chemical-in-crucible" method. This doping technique allows one to deposit a greater number of doped layers, such that preforms with large core sizes and more complex RE doping profiles can be realized [15]. An aluminosilicate fiber, which was in-situ doped with $\mathrm{Yb}$, was successfully fabricated and exhibited a slope efficiency of $79 \%$. Using this MCVD chemical-in-crucible technique, it is possible to heat the rare-earth precursor directly within the MCVD glassware on the lathe in close proximity to the deposition zone, which increases 
versatility while maintaining high doping uniformity along the preform length [16]. Due to the reasonable volatility of lanthanide-based chelate complexes in conjunction with MCVD, preforms can be doped with a high concentration of REs in the gas-phase at crucible temperatures of $\sim 200{ }^{\circ} \mathrm{C}$. Because modifier ions (such as for example $\mathrm{Al}_{2} \mathrm{O}_{3}$ and / or $\mathrm{P}_{2} \mathrm{O}_{5}$ ) can be incorporated simultaneously during the incorporation of the $\mathrm{RE}$ and silica, less rare-earth clustering occurs during the core processing when compared with solution-doping for an equivalent doping level [17]. This innovative chemical-in-crucible preform fabrication technique allows one to dope silica glass using a wide range of precursors.

Another route of interest for the development of new silica-based optical fibers using MCVD consists of nanoparticle doping. Such fibers possess both the advantages of silica (i.e., transparency, cost, chemical and mechanical durability), and also some of those of the nanoparticles. It is therefore possible to control the RE optical response independent of the nanoparticle composition. Different techniques have been developed to process particle-containing silica fibers.

One such technique consists of synthesizing the nanoparticles directly in-situ in the preform, as is illustrated in Figure 1.

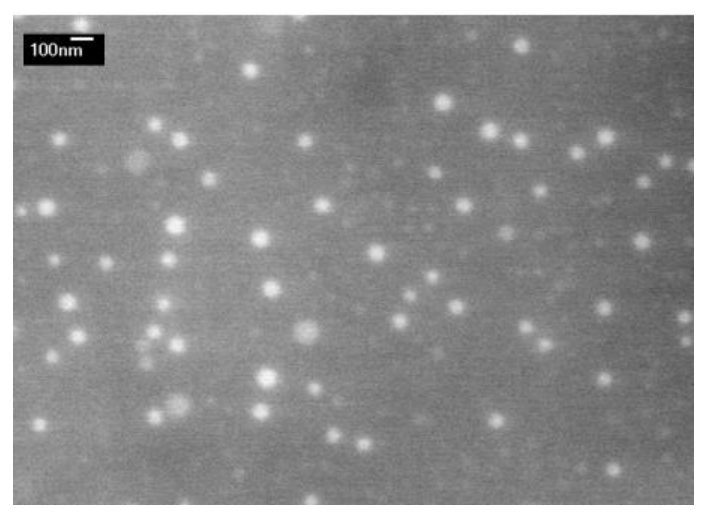

Figure 1. SEM images of particle-containing silica core. Particles were obtained by adding $\mathrm{MgCl}_{2}$ in the core (figure courtesy of Dr. Wilfried Blanc, University of Nice Sophia Antipolis, France).

A phase-separating agent, such as magnesium oxide, is added to induce the formation of nanoparticles [18]. The concentration of those phase separating agents was found to have a considerable impact not only on the composition, but also on the average dimension of the nanoparticles. Blanc, et al., found that nanoparticles grown during the fabrication of the preform can be preserved during fiber draw [19]. Another technique to process nanoparticle-containing silica glass consists of forming the particles directly in the fibers by heat treating the silica glass after drawing. For example, Yb-doped nano-crystalline yttrium Aluminum garnet (YAG) in a silica-based preform was fabricated using MCVD with solution doping followed by thermal annealing [20]. An alternative technique consists of adding the nanoparticles in the silica soot through conventional solution doping. In this approach, nanoparticles are first formed by solution chemistry and are then added in the silica soot, which is porous, by solution doping methods. The nanoparticles must have a proper size to limit scattering and must be durable during the core processing and fiber drawing. As reported in [21], doping using $\mathrm{Er}^{3+}$-doped $\mathrm{Al}_{2} \mathrm{O}_{3}$ nanoparticles in an MCVD-compatible process was found to lead to a homogenous glass and thus to improve the performances in terms of erbium homogeneity along the fiber length for standard doping levels. The advantage of this technique is that it is possible to realize a "conventional" silica optical fiber where the REs' local environment is different from that of the host silica, affording enhanced spectroscopic properties [22,23].

Those two techniques have been used also for the fabrication of nanoparticles containing non-silica glasses and fibers. More details about the latest development of such fibers can be found in Section 3 . 
Another innovative method, the direct nanoparticles deposition (DND) process, also has been used as a technique that allows for homogeneous core glasses with unconventional properties. In this process, soot deposition consists of the combustion of gaseous and atomized liquid raw materials occurring in an atmospheric oxyhydrogen flame, as is illustrated in Figure 2.

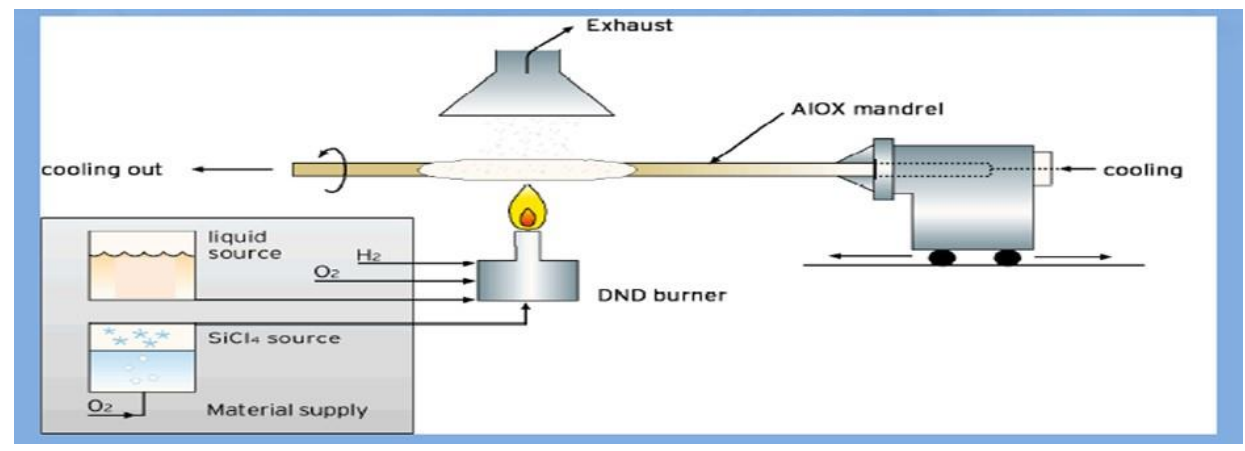

Figure 2. Schematic of the direct nanoparticles deposition (DND) process.

This technique leads to the formation of particles with a 10-100-nm size, which are deposited on a mandrel. Following this deposition, the mandrel is removed and the soot body is dried, cleaned, sintered and collapsed into a furnace. The collapsed core is then processed into a dense preform and drawn to a fiber. The particle deposition process can be precisely monitored for each layer permitting accurate, automatic and simultaneous control of RIP and RE dopant concentration. The advantage of this process is the possibility to fabricate highly uniform and reproducible soot, which possesses hundreds of accurately controlled layers. By independently tailoring the RE doping and RIP, this technique allows one to manufacture fibers that possess a non-step-index profile or that have partially-doped cores. Recent improvements in this technology have focused on finer control over the dopant concentration in order to better control the RIP and on the microstructure of the doped glass. This has been realized through a deeper understanding of the thermal, chemical and microfluidic mechanisms occurring in the DND burner and flame during the soot deposition [24]. LMA (large-mode-area) fibers with a 20-30- $\mu$ m core diameter and a core numerical aperture (NA) of 0.06-0.08 have been successfully fabricated using this process [25,26].

Another alternative to conventional methods for silica fiber preform fabrication is the surface-plasma chemical vapor deposition (SPCVD) process. Unlike MCVD, in SPCVD, the halide precursor's conversion to an oxide takes place at a reduced pressure and at a lower temperature due to a microwave-induced plasma. In this process, an incomplete and partial oxidation of the metal species occurs in the gas phase during the formation of the oxide layer on the inner surface of a substrate tube. This technique offers significant opportunities in controlling the stoichiometry of the deposited oxides and allows for the synthesis of glasses under reducing conditions. The SPCVD technique was first applied to the fabrication of preforms with an Er-doped silica core and fluorine-doped silica cladding [27] and later for the fabrication of a Bi-activated aluminosilicate core/pure-silica-clad fiber [28]. Recently, Savel'ev, et al., reported the preparation of two- and three-layer light-guiding structures using SPCVD of doped $\mathrm{SiO}_{2}$ [29]. As explained in [30], it is possible to reduce the $\mathrm{OH}$ content in glass due to the true vapor phase deposition from hydrogen-free starting materials and so to process better fibers for signal amplification in the whole near-1.3- $\mu \mathrm{m}$ wavelength spectral range.

Yet another technique to fabricate novel silicate-based preforms is based on powder sintering [31]. In this technique, a tube containing silica is fused to create the core. The so-called REPUSIL (an acronym for "Reactive Powder Sintering of Silica") process, which was based on this powder sintering method, was developed by Heraeus Quartzglass and the Leibniz Institute of Photonics Technology (IPHT, Jena, Germany) [32]. This technique, the schematic of which can be found in [33], can be considered as a modification of the solution doping process. Starting materials are high-purity gas phase-formed silica 
nanoparticles and water-soluble compounds. In this technique, the $\mathrm{SiO}_{2}$ particles are homogeneously dispersed in a liquid suspension. The powders are dried, purified and sintered into homogeneous bubble-free RE-doped silica rods that exhibit negligible variation in the radial/axial doping level or in the refractive index level. Using this technique, single-mode optical fibers have been successfully processed with reduced fabrication costs due to the replacement of the thick and expensive cladding silica tube of the fiber preform (fabricated by MCVD) by synthetic pure silica powder. With this technique, it is possible to prepare very large and homogeneously-doped active fiber cores. Fiber with a background attenuation of $20 \mathrm{~dB} / \mathrm{km}$ and with a slope efficiency of $80 \%$ was reported in [34]. Fibers with similar laser efficiencies as fibers produced by the MCVD/solution doping technology were fabricated using the REPUSIL process [30].

Finally, a new technique was recently reported in [35] to process rare-earth doped fiber. This technique combines the atomic layer deposition (ALD) with conventional modified chemical vapor deposition (MCVD). ALD has been found to be an effective method to add $\mathrm{Yb}$ ions at the surface of the porous silica layer of an MCVD-soot. Homogeneous $\mathrm{Yb}$ doping along the fiber axis over a $1 \mathrm{~km}$-long fiber with low background losses has been reported [36]. The ALD fiber, with a Yb slope efficiency of $80 \%$, exhibited less photodarkening as compared to a fiber with similar doping fabricated by the MCVD-solution doping technique. This technique also was used to fabricate $\mathrm{Bi} / \mathrm{Al}$ co-doped silica optical fibers, with a concentration of $\mathrm{Bi}$ and $\mathrm{Al}$ ions, respectively, of 150-180 and 350-750 ppm in the fiber preform core [37].

\section{Nanoparticle-Doped Glasses and Fibers}

Two types of fluorescent nanocrystals (NCs)-upconversion nanocrystals (UPNCs) and nanodiamond (ND) - have attracted particular interest for photonics applications in recent years [38]. Lanthanide ions doped into UPNCs enable emissions in the ultraviolet to visible spectral range due to the upconversion of two or more near-infrared excitation photons. Recently, highly concentrated active lanthanide ion-doped UPNCs were found to emit high brightness upconversion by excitation enhancement $[39,40]$. This new generation of UPNCs is particularly promising for various applications, such as, for example, biological sensing, anti-counterfeiting, photon energy management and volumetric displays [41,42]. Fluorescent NDs containing nitrogen-vacancy color centers show room-temperature single-photon emission, spin polarization and read-out in the visible spectral range, which enables optical detection of magnetic resonance and a range of other quantum sensing properties [43-46].

Many applications would benefit from the incorporation of NCs in a photonic platform, such as optical fibers. Incorporation of NCs into the core glass of optical fibers ensures efficient and robust excitation and collection of the fluorescence from NCs in a robust device. However, the addition of NCs that have tailored nanophotonic properties in glass is still a challenge.

To date, the almost exclusively used approach to integrate luminescent NCs into glass is the glass-ceramic method. This method relies on the in-situ growth of NCs in a glass matrix $[47,48]$. In this method, the crystals seeds that grow into NCs are formed by the ions that diffuse inside the glass by heat treating the glass containing precursor ions above the glass transition temperature of the host [49-52]. Remarkable progress in embedding a wide range of oxide-, fluoride-, chalcogenide- and metal-based NCs into glass using this technique has been achieved [53-55]. However, the majority of NCs that can be made via alternative synthesis methods cannot be grown in-situ in glass. For example, it is not possible to grow nanodiamond or heterogeneous nanostructures in glass, which limits the ability to engineering optical properties at the nanoscale [56-60]. For NCs that can be grown in-situ, it is still challenging to reach a high level of compositional and nanostructural control over the NCs. For example, it is difficult to incorporate lanthanide ions in in-situ-grown NCs, such as UPNCs with controlled concentrations and arrangement at specific sites. Additionally, the maximum $\mathrm{Ln}^{3+}$ concentration that can be obtained in these NCs is limited by the limited solubility of $\mathrm{Ln}^{3+}$ ions [61-63], their short-distance diffusion in glass [64-66] and the large volume fractions of $25 \%-35 \%$ of the in-situ 
grown NCs (NCs/glass vol/vol) [67,68]. Furthermore, the continued growth of in-situ-grown NCs, which could occur during a post-annealing or during a reheating process, such as fiber drawing, inhibits the application of glass ceramics [69]. The continued growth of NCs can increase the light scattering and so the optical loss in the resulting glass/fiber. Alternatively, controlled growth of NCs in the glass during fiber drawing is challenging and, thus, to date, has resulted in relatively high loss fibers [70,71].

The ever-advancing synthetic techniques of NCs using a wide range of techniques such as wet chemistry [72-74], laser ablation [75], ball milling [58,59] and detonation [60] have shown exceptional control over emitting center concentration, crystallite phase, size, shape, composition and nanostructure. The technique, which consists of the synthesis of the NCs and then of their addition in the glass, gives a clear advantage as compared to the glass-ceramic technique for the synthesis of hybrid material, as with this novel fabrication technique, one can control the composition and nanostructure of the as-prepared NCs and glasses, overcoming the limitation of the glass ceramics method. One approach is to prepare NCs, then to pre-mix them with the glass powder and, finally, to melt the batch into a hybrid glass. However, as explained in [76,77], an insufficient dispersion of the NCs had been obtained using this technique [76]. Dissolution of the nano-/micro-scale crystals or a decrease in the transmission of the resulting glass was reported in [78-82]. For example, a reduction of the crystal size from 18.3 down to $14 \mu \mathrm{m}$ was reported when melting the batch at $520{ }^{\circ} \mathrm{C}$ for $10 \mathrm{~min}$ [79]. As explained in [83], an extremely high risk of completely dissolving the nanoscale crystals can occur during the melting. For example, melting of $\mathrm{Er}^{3+}: \mathrm{Al}_{2} \mathrm{O}_{3}$ nanoparticles containing borosilicate glass batches resulted in glasses that did not show any evidence that the nanoparticles remained in the glass after melting [83].

Recently, an alternative approach, the direct doping of NCs into tellurite-based glass melts, was developed [84-87]. This approach comprises a two-temperature melting procedure. First, the batch of crystalline raw materials without NCs is melted at a higher temperature to obtain a clear, homogenized glass melt; then, the temperature is decreased to a point where the glass melt has an optimum viscosity in terms of being able to disperse NCs and being able to be cast into a mold. At this doping temperature, the NCs are added and mixed into the glass melt and then dwell for a short time in the glass melt to allow dispersion before casting the NC-doped melt into a mold. To date, the success of the approach has been demonstrated for embedding ND and UPNCs in tellurite glasses and fibers.

The direct doping approach was, for the first time, employed to embed the nitrogen-vacancy (NV) center containing NDs in tellurite glass using a batch melting temperature of $900{ }^{\circ} \mathrm{C}$, a doping temperature of $700^{\circ} \mathrm{C}$ and an ND doping concentration of 9 and 280 ppm by weight [84]. Fibers were made from these glasses by first fabricating preforms using billet extrusion at $350{ }^{\circ} \mathrm{C}$ followed by fiber drawing at $\sim 400{ }^{\circ} \mathrm{C}$. Raman, photoluminescence and second order autocorrelation experiments confirmed the presence of NDs in the glass, preform and fiber samples. This result suggests that the use of glass processing temperatures well below the doping temperature did not affect the NDs embedded in the glass. These first fabricated glasses and fibers exhibited relatively high loss in the visible $(>100 \mathrm{~dB} / \mathrm{m})$ [84]. NDs were found to act as a chemical reducing agent. They react with higher valence species in the melt, such as tellurium (IV) ions (constituent of the glass network), gold ions (dissolved in the melt via corrosion of the gold crucible) and oxygen (dissolved in the melt via interaction with the atmosphere), resulting in the formation of lower valence species, such as gold nanoparticles (GNPs) and reduced tellurium species, as well as in the oxidation (burning) of the NDs and also to the undesirable disappearance of the carbon atoms of the NDs, as they are consumed in all of these reactions. Additionally, the fibers exhibit high loss in the visible due to the formation of the GNPs and reduced tellurium species [85].

The change of the glass composition from a Na-Zn-La-tellurite (TZNL) glass to a Na-Zn-tellurite (TZN) glass with lower melting temperature combined with fine-tuning of the glass fabrication conditions prevented the formation of undesired species (GNP, reduced tellurium), leading to 
ND-doped fibers with low loss $(\leq 10 \mathrm{~dB} / \mathrm{m}$ at the emission wavelength range (600-800 $\mathrm{nm})$ of NV centers in ND) (Figure 3a) [86].
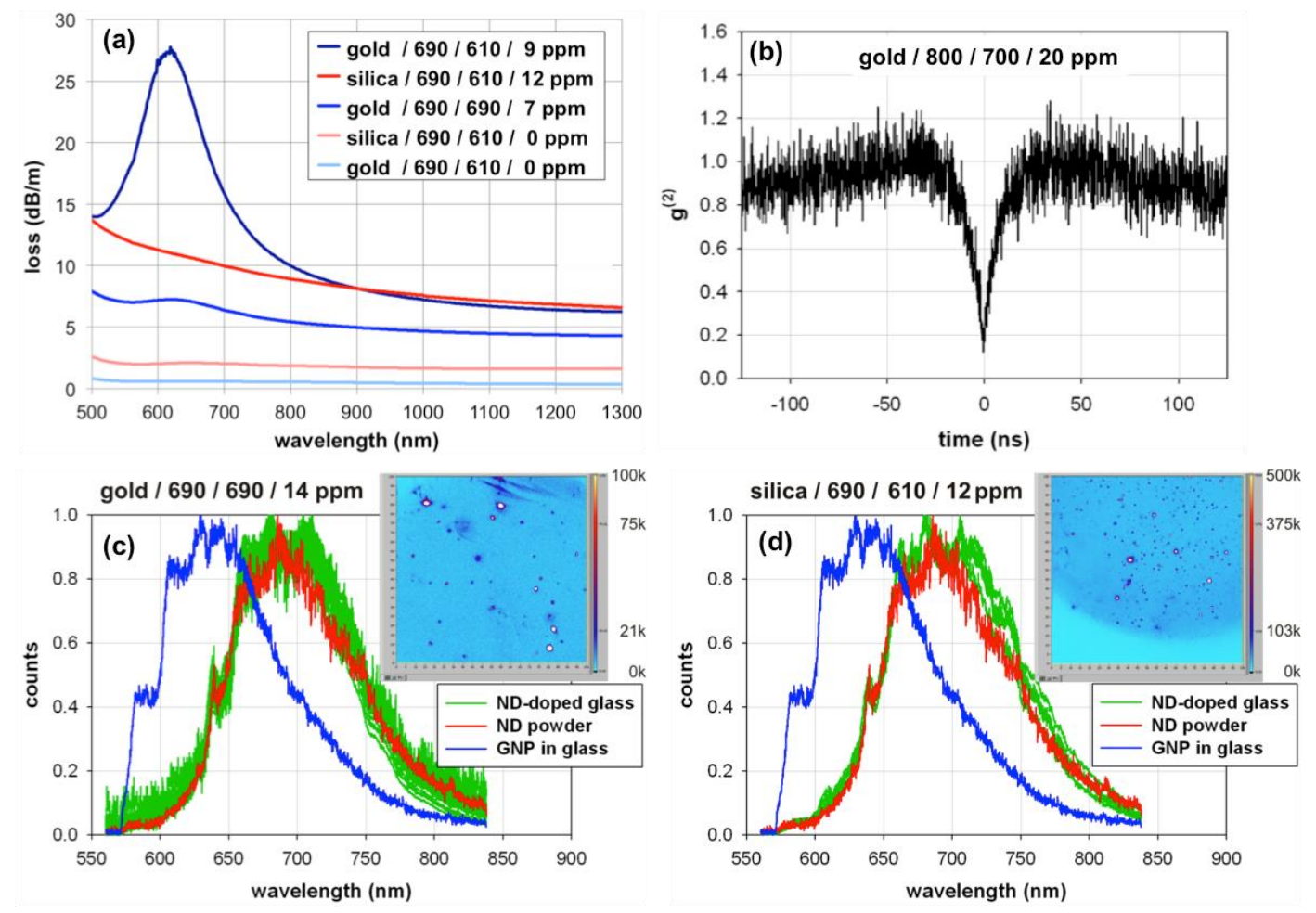

Figure 3. (a) Light attenuation spectra of nanodiamond (ND)-doped and undoped Na-Zn-tellurite (TZN) fibers; (b) background-corrected second order autocorrelation function $\mathrm{g}^{(2)}$ of nitrogen-vacancy (NV) emitters in ND-doped Na-Zn-La-tellurite (TZNL) fiber; $(\mathbf{c}, \mathbf{d})$ confocal microscope images and fluorescence spectra of emitters in ND powder and ND-doped TZN tellurite fiber samples and of gold nanoparticles (GNPs) in TZN tellurite glass. The legends indicate crucible material/batch melting temperature in ${ }^{\circ} \mathrm{C} /$ doping temperature in ${ }^{\circ} \mathrm{C} / \mathrm{ND}$ doping concentration.

The loss of these improved ND-doped fibers is dominated by scattering from agglomerated NDs, indicating the need to further improve the dispersion of NDs in the glass during the doping step. The presence of NV emitters (and thus, survival of ND in the glass) was demonstrated by their single photon dip (Figure 3b) and fluorescence spectral behavior (Figure 3c,d). For fiber samples doped with $12-20 \mathrm{ppm} N D$, the ND survival ratio was found to be $1 \%-6 \%$ which is sufficient to fabricate a practical fiber length required for single photon quantum applications and magnetic field sensing.

Building on the success in doping ND into TZN glass, $\mathrm{LiYF}_{4}: \mathrm{Yb}, \mathrm{Er}$ UPNCs were successfully doped into TZN glass and fiber [87]. As for the ND doping, fine-tuning of the doping temperature and time was critical to balance NC dissolution and dispersion (Figure 4a).

The comparison of $\mathrm{Er}^{3+}$ upconversion spectra of NC-doped glass and fiber with the spectra of $\mathrm{NC}$ powder and $\mathrm{Er}^{3+}$-doped glass (Figure $4 \mathrm{~b}$ ) validated the survival of the UPNCs in the glass while also indicating partial dissolution (30-60 vol\%) of the NCs. Using upconversion scanning confocal microscopy, the 3D in-situ visualization of UPNC dispersion in glass was achieved for the first time (Figure 4c). All glasses show high optical transmittance similar to the maximum transmittance of undoped TZN glass (Figure 4b). Similarly, at a 1.3- $\mu \mathrm{m}$ wavelength (where $\mathrm{Er}^{3+}$ and $\mathrm{Yb}^{3+}$ ions do not absorb), the light attenuation loss of the NC-doped fiber is within the range of undoped and $\mathrm{Er}^{3+}$-doped fiber $(0.1-0.3 \mathrm{~dB} / \mathrm{m}$ ) (Figure $4 \mathrm{~d}$ ). Simulations of the glass transmission at $500 \mathrm{~nm}$ and fiber loss at $1.3 \mu \mathrm{m}$ based on the Rayleigh-Gans-Mie theory indicate that the negligible light scattering of the NC-doped glass and fiber samples is caused by low NC doping concentration $(<170 \mathrm{ppm})$, reduced 
NC size due to partial dissolution (from 60 down to $46 \mathrm{~nm}$ diameter, i.e., $\sim 50 \%$ dissolution volume fraction) and the absence of agglomeration.
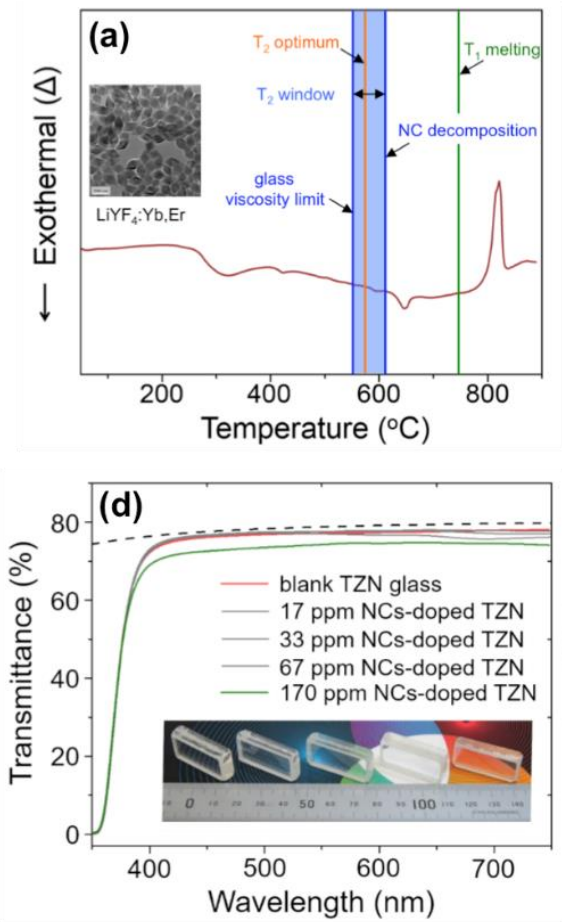
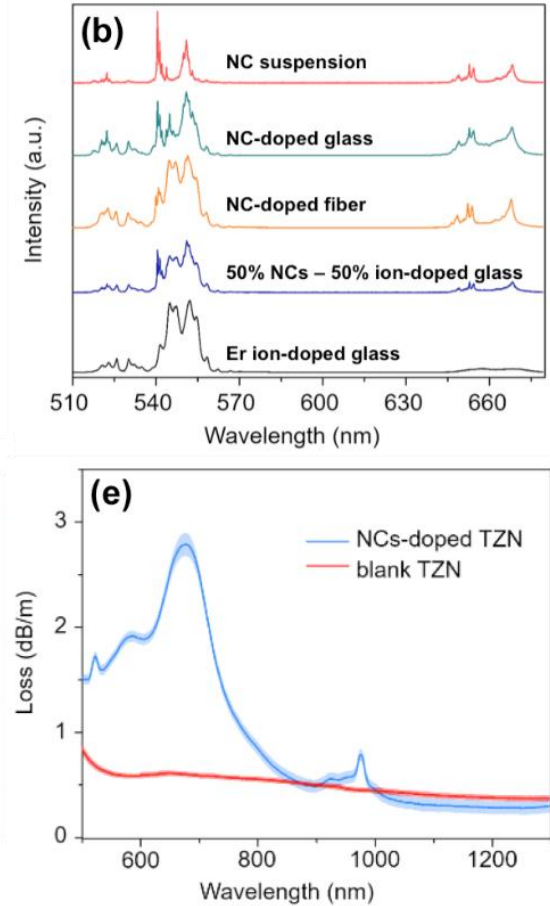

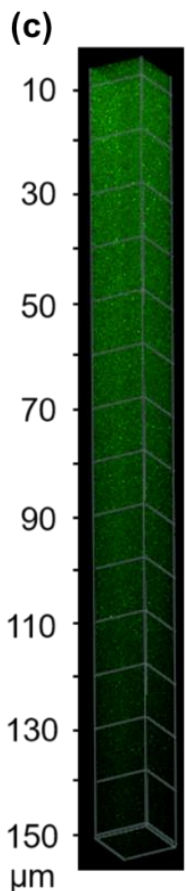

Figure 4. (a) Schematic showing SEM image and Differential Thermal Analysis (DTA) plot of upconversion nanocrystals (UPNCs), as well as batch temperature and doping temperature window; (b) Normalized upconversion spectra of NC suspension, NC-doped TZN glass and fiber, $\mathrm{Er}^{3+}$-doped TZN glass and simulated spectrum of $50 \% \mathrm{NCs}$ and $50 \% \mathrm{Er}^{3+}$ ions in TZN glass; (c) 3D reconstruction of emitters in NC-doped TZN glass by stacking confocal microscopy images; (d) Transmittance spectra and photographs of NC-doped TZN glasses; (e) Optical attenuation spectra of NC-doped and undoped (blank) TZN glass fibers.

To summarize, in the direct doping approach, the separation of the glass fabrication procedure into a batch melting step and a subsequent NC doping step allows the use of lower temperatures and shorter times for doping NCs into glass, which is crucial to ensure the survival of NCs in the glass melt and glass quality preservation. In addition, the direct doping step allows the control of the NC concentration down to low concentrations, e.g., as required for ND-doped glass. Another advantage of the direct doping approach is the ability to select the NC and glass composition that does not undergo nucleation and crystal growth during fiber drawing, enabling the fabrication of low-loss fiber with embedded NCs at well-defined concentrations. These features make the direct doping method a suitable technique to add luminescent NCs in glass. Processing of glasses below the doping temperature, such as extrusion and fiber drawing, did not affect the NC dispersion and dissolution, highlighting the outstanding potential of the direct doping approach for NC-doped fiber fabrication.

The main challenges of the direct doping approach are ensuring the survival and dispersion of the NCs in the high temperature glass melt. These two challenges pose contrasting requirements to the doping temperature, and thus, viscosity and dwell time of the NCs in the batch melt, and therefore, demand careful optimization of these glass doping conditions. The example of the preparation of ND and UCNP-doped TZN glasses in this section provides a new and feasible method to develop nanocrystals-based hybrid glasses and fibers. The protocols illustrated here are very useful to greatly expand the combination of different glass matrices and a variety of NCs with photonic, electronic and magnetic properties of interest. Although tellurium is potentially disruptive to the tellurite glass 
network in a corrosive environment and poses safety concerns in widely using tellurite-based glass, the tellurium toxicity due to such possible leakage is beyond the scope of the review. In addition, it is believed that the safety concerns could be significantly relaxed by further coating a robust and protective polymer cladding around the fiber.

While the direct doping approach enables embedding of NCs in low concentrations into glass, this poses the challenge of the characterization of the NCs in the glass. Transmission electron microscopy (TEM) is a widely-used method to image NC in glass. However, for the low doping concentrations used to date for the direct doping approach $(<200 \mathrm{ppm}$ in weight, which equals the occurrence of less than five NCs of $50 \mathrm{~nm}$ in diameter in $1 \mu \mathrm{m}^{3}$ ), the small sampling volume of a glass particle being sufficiently thin for TEM $\left(<0.01 \mu \mathrm{m}^{3}\right)$ requires sampling more than 20 thin glass particles to find an NC, which is impractical in terms of sample preparation time. The use of luminescent NC allows for the use of confocal microscopy to characterize the properties of $\mathrm{NC}$ in glass and thereby to determine the survival and dissolution of NC in glass.

\section{Semiconductor Core Optical Fibers}

Another significant area of optical fiber materials' development involves the fabrication, optimization and application of glass-clad fibers comprising semiconductor cores. Semiconductors, the work-horse of the optoelectronics industry, enable all modern electronic conveniences, as well as a growing number of photonic devices; i.e., silicon photonics $[88,89]$. The potential to bring together silicon photonics with the enhanced nonlinearities and infrared (IR) transparency of semiconductors in a fiber format has generated considerable global attention to this new field. A number of papers reviewing the advances on this topic have been published to which the reader is referred [90-96]. The focus here is a summary of the materials' development, optimization and utilization of semiconductor optical fibers.

Crystalline silicon (Si) fibers were first reported in 1996 and were grown by the micro-pull-down method [97]. Perhaps ahead of their time, such fibers did not generate much attention until a decade later when high-pressure chemical vapor deposition (HP-CVD) was employed to realize silicon inside the open capillaries of a silica $\left(\mathrm{SiO}_{2}\right)$ photonic crystal fiber [98]. The advantages of the HP-CVD approach is that both amorphous and crystalline silicon fibers are possible, and the semiconductor core is inherently clad in glass. However, both micro-pull-down and HP-CVD processes are slow, which limits scalability.

In order to address this short-coming, the molten core method was employed to realize long glass-clad silicon optical fibers [99]. In the molten core method (MCM), it is crucial to select the core phase, such that it is molten at the temperature where the cladding glass draws into fiber. Given the significant cooling rate of the fiber draw process, the MCM was originally developed to fabricate fibers from unstable glasses prone to crystallize [100]. Accordingly, it was entirely unexpected that a highly crystalline core would result. Presently, HP-CVD and MCM are the two approaches employed to process semiconductor optical fiber, with the latter being practiced globally.

With these two principal tools in place to fabricate glass-clad semiconductor core fibers, a number of other unary and binary systems were developed, including doped-silicon [101], germanium (amorphous [102] and crystalline [102-104]), selenium [105], tellurium [106], silicon-germanium alloys [107], selenium-tellurium alloys [108], indium antimonide [109] and zinc selenide [110,111]. In addition to new core phases, efforts also were undertaken to develop cladding glasses that were more closely matched in their thermo-physical properties to those of the semiconductors they encapsulate [106,112]. Examples of glass-clad crystalline semiconductor core optical fibers are shown in Figure 5a,b; respectively, these are a polymer-coated, borosilicate glass-clad germanium (Ge) core fiber and an uncoated silica glass-clad silicon $(\mathrm{Si})$ core fiber. 


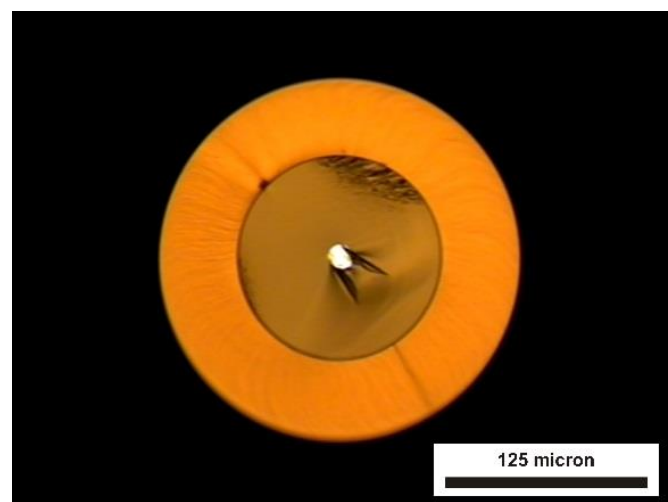

(a)

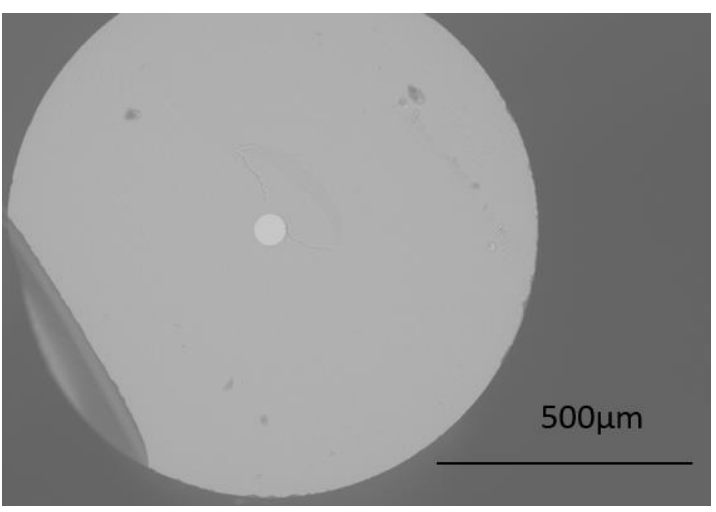

(b)

Figure 5. (a) Optical micrograph of a polymer-coated, glass-clad germanium (Ge) core optical fiber and (b) An electron micrograph of an uncoated glass-clad silicon core optical fiber.

It is also important to note that, unlike traditional glass fibers, additional solid-state and liquid-phase chemistry not only can take place during the fabrication of these fibers, but can be strategically employed. Two excellent examples are the fabrication of zinc selenide (ZnSe) fibers using Zn and Se compounds [111,113] and silicon fibers realized from aluminum [114]; in both cases, reactions occur in-situ during the draw, opening the door to an even richer range of materials and chemical/process routes to intriguing new fibers not possible using conventional methods.

Though considerable progress has been made over the past decade [95], glass-clad semiconductor core optical fibers generally perform on par with their planar waveguide analogs; at least in terms of optical attenuation with losses on the order of $\mathrm{dB} / \mathrm{cm}$ levels; for a comparison of loss values, see [95]. While the exact loss mechanisms that dominate are still a source of debate and investigation, a number of studies have begun to narrow down the most critical. For example, in planar waveguides, loss is often dominantly controlled by surface roughness. However, in these glass-clad semiconductor core optical fibers, the semiconductor/glass (i.e., core/clad) interface is exceedingly smooth, and so, roughness should not play as significant a role in the measured loss values $[115,116]$. In both the HP-CVD and MCM approaches, the resultant core is polycrystalline (though, as noted, the HP-CVD process can produce amorphous semiconductors, as well). Accordingly, scattering of light from impurities or defects that aggregate at the grain boundaries has been observed and can lead to loss even in crystallographically cubic materials (e.g., silicon, germanium, indium antimonide) that are optically isotropic [116]. Stress-optic effects may also play a role. The effect of core size and fiber processing on grain size has been systematically studied and, when normalized to the silicon core diameter, was found to increase with diameter and decrease with cooling rate, though no preferential grain orientation was observed relative to the fiber axes [117].

Less of an issue in HP-CVD than the MCM, oxide contaminations from the dissolution of the cladding glass, typically $\mathrm{SiO}_{2}$, into the core melt can lead to scattering and loss [95]. More recently, though, such issues of oxide contamination have been mitigated through in-situ reactive chemistry, and silicon fibers with negligible oxygen levels have been produced. This is quite remarkable given that the fiber is drawn inside an oxide glass cladding tube at a temperature in excess of $500 \mathrm{~K}$ above the semiconductor's melting point [118,119]. Lastly, loss also will be dependent on the doping of the semiconductor employed, though a systematic study of dopant species and concentration has not been undertaken as yet.

In addition to the aforementioned efforts to develop semiconductor core fibers from a wider range of core materials and cladding compositions, significant work has also gone into the processing of the fibers in order to both understand the science of the crystal formation and to optimize its single crystallinity. 
Following the first in-depth analysis of the longitudinal single-crystallinity in these fibers [120], methods investigated to either refine or recrystallize the crystalline semiconductor core include thermal annealing [121], core geometry (circular versus square cross-section) [122], core size [117], tapering [123] and laser recrystallization $[124,125]$. These processes do indeed influence the single crystallinity of the semiconductor core and have led to longer single crystalline lengths and slightly lower losses [95]. However, loss does remain a limitation for the use of these fibers in photonic applications where a fiber geometry is generally beneficial.

It did not take long after the first HP-CVD silicon fibers were fabricated for efforts to assess their practical utility to begin [126]. Not surprisingly, from the perspective of applications, the most attention has related to nonlinear optics. Initial activities focused on all-optical modulation in amorphous silicon of a fairly small core size [126]. Subsequently, the nonlinear transmission [127], two-photon absorption (TPA) [128], cross-phase modulation (XPM) [129], four-wave mixing (FWM) and super-continuum generation (SC) [130] all have been investigated. As nonlinear effects generally are enhanced at small core sizes, tapering of the fiber also has been employed and has yielded soliton generation [131] and the first observation of nonlinear transmission within a polycrystalline silicon waveguide of any type [132].

Semiconductor fibers have also been used for the production of microspheres [133]. Such micro-spheres and analogous micro-cylinders have proven useful for a variety of high-Q resonators [134,135], including tunable ones based on thermal and Kerr-related nonlinearities [136-138]. Additionally, the high refractive index, Raman gain and strong photoconductivity have permitted the realization of fiber-based anti-resonant reflecting optical waveguides (ARROW) [139], mid-infrared (MIR) light sources [140] and RF antennas [141].

Perhaps possessing the greatest future potential are novel fiber-based devices that take advantage of electronic transport and junction effects in doped semiconductors. In these cases, the devices benefit from the fiber geometry and core size for light absorption and efficient charge transport while without concern for the relatively high optical attenuations measured to date. To date, such devices include p-i-n [142] and p-n [143] in-fiber junctions, which can operate at GHz bandwidths [144], as well as a series of microwire radial solar cells [145-147].

\section{Innovative Chalcogenide Glasses and Optical Fibers}

This section discusses important advances in chalcogenide glasses and fibers. In recent years, applications have increased for fibers operating in the mid-infrared (mid-IR) region, which can be defined as the 2-20- $\mu \mathrm{m}$ electromagnetic spectral range. Indeed, this spectral region covers the atmospheric transmission windows $(3-5 \mu \mathrm{m})$ and $(8-12 \mu \mathrm{m})$ in which thermal imagery (military and civilian) is routinely employed. Furthermore, the mid-IR window corresponds with the molecular fingerprint region where molecules have strong absorption bands. In this context, the development of mid-IR transparent materials and optical fibers is essential. Consequently, numerous research activities for developing innovative mid-IR optical fibers and, more particularly, chalcogenide optical fibers have been reported. In this section, the transmission window of different chalcogenide fibers will be presented and discussed depending on the composition and purification process as will be ordinary and original fiber designs. Finally, applications in mid-infrared spectroscopy based on passive or active chalcogenide fibers will be discussed.

Chalcogenide glasses (ChGs) contain at least one chalcogenide element, such as S, Se and Te [148]. Depending on the composition, ChG fibers can be transparent, for example from $1 \mu \mathrm{m}-6.5 \mu \mathrm{m}$ for an As-S glass fiber [149] and from 1.5-10 $\mu \mathrm{m}$ for an As-Se fiber [150]. As is illustrated in Figure 6a, short wave and long wave absorption edges are shifted to the mid-IR with substitution of $\mathrm{S}$ for Se and/or Te, which is related to an increase of the average glass component molar mass. 


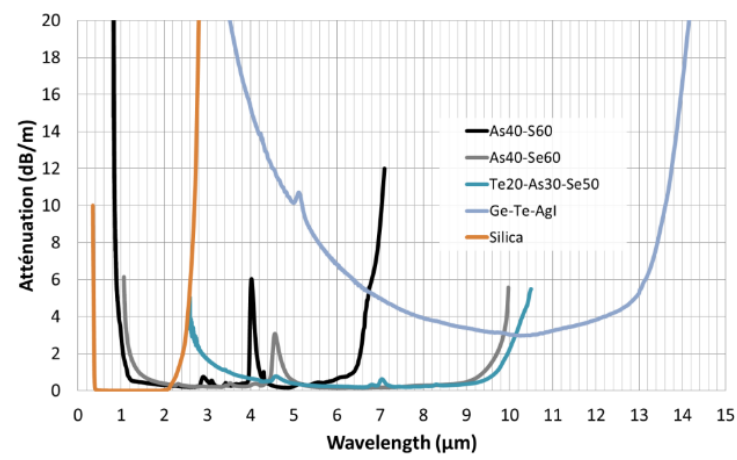

(a)

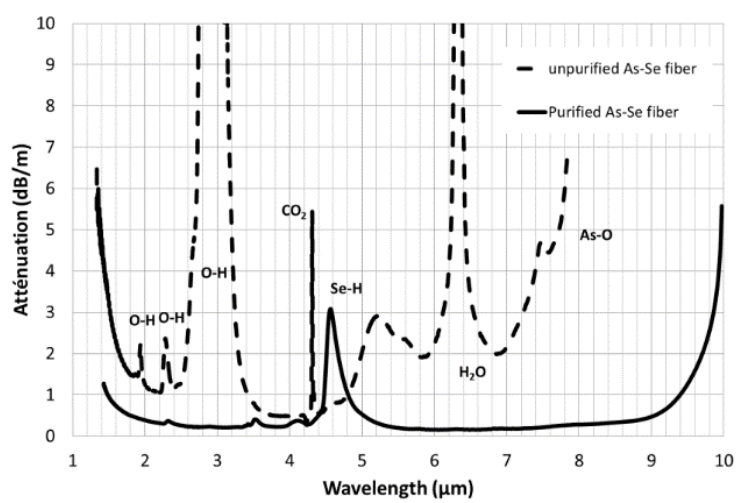

(b)

Figure 6. Mid-infrared transmission of chalcogenide optical fiber: (a) Depending on the chemical composition and (b) Role of the purification processes.

For example, when all sulfur and selenium atoms are substituted by tellurium atoms, the chalcogenide fiber can be transparent to 13-14 $\mu \mathrm{m}$ [151]. The attenuation curve of a chalcogenide fiber is also strongly linked to the optical quality of the glass. Indeed, without any purification treatment, strong absorption bands, due to the presence of impurity chemical bonds, can be observed. Table 1 defines the mid-IR absorption signatures of different impurities that can be observed in chalcogenide glasses and fibers $[150,152,153]$.

Table 1. Mid-infrared signatures of the impurity absorption bands in chalcogenide fibers $[150,152,153]$.

\begin{tabular}{ccccccccccc}
\hline Impurity & $\mathbf{O}-\mathbf{H}$ & $\mathbf{S}-\mathbf{H}$ & $\mathbf{S e}-\mathbf{H}$ & $\mathbf{T e}-\mathbf{H}$ & $\mathbf{C O}_{\mathbf{2}}$ & $\mathbf{C}-\mathbf{S}$ & $\mathbf{H}_{\mathbf{2}} \mathbf{O}$ & $\mathbf{A s}-\mathbf{O}$ & $\mathbf{S e}-\mathbf{O}$ & $\mathbf{G e}-\mathbf{O}$ \\
\hline & 1.44 & 2.5 & 2.30 & 5.0 & 4.26 & 4.94 & 2.29 & 7.5 & 10.4 & 7.5 \\
& 1.92 & 3.1 & 3.45 & & & & 2.32 & 7.9 & 13.9 & $7.9-8.1$ \\
Position $(\mathrm{s}) \lambda(\mu \mathrm{m})$ & 2.92 & 3.7 & 3.55 & & & & 2.83 & $8.6-8.9$ & & \\
& & 4.0 & 4.55 & & & & 6.32 & & & \\
& & & & & & & 7.5 & & & \\
\hline
\end{tabular}

In Figure 6b, the attenuation curves of an $\mathrm{As}_{2} \mathrm{Se}_{3}$ fiber with and without purification treatments are compared. The commercial products (even high purity products) contain different impurities, oxygen, hydrogen, carbon and transition metals, and the raw materials are very sensitive to oxygen and moisture. For these reasons, chalcogenide glass matrices have to be synthesized under neutral atmosphere (vacuum) and have to be purified. Without treatment, strong absorption bands can be observed due to the presence of $\mathrm{O}-\mathrm{H}, \mathrm{Se}-\mathrm{H}$ and $\mathrm{As}-\mathrm{O}$ chemical bonds and due to the presence of $\mathrm{CO}_{2}$ and $\mathrm{H}_{2} \mathrm{O}$ molecules, in the glass matrix (Figure $6 \mathrm{~b}$ ).

Several purification methods have been reported: by purification of the raw elements before the synthesis [154] or by using microwave treatment before the synthesis [155]. The lower attenuation losses reported for chalcogenide fibers have been obtained by purifications of the raw materials, before the synthesis, followed by distillations of the glass with the addition of chemical getters, such as, for example, $\mathrm{TeCl}_{4}$ and $\mathrm{Al}$ or $\mathrm{Mg}$ metal. Those physical and chemical treatments permit the removal and/or reduction of impurities, hence attenuation. In addition, the distillation processes permit the removal of refractory impurities, such as carbon particles, $\mathrm{SiO}_{2}$ particles (from the synthesis crucible) and $\mathrm{Al}_{2} \mathrm{O}_{3}$ particles that can induce strong scattering effects. The minimum of attenuation of chalcogenide fiber reported reaches $12 \mathrm{~dB} / \mathrm{km}$ at $3 \mu \mathrm{m}$ and $14 \mathrm{~dB} / \mathrm{km}$ at $4.8 \mu \mathrm{m}$ in an $\mathrm{As}_{2} \mathrm{~S}_{3}$-based fiber [149]. In a selenium-based fiber, optical losses less than $50 \mathrm{~dB} / \mathrm{km}$ at $3.7 \mu \mathrm{m}$ have been reported in [156]. Concerning tellurium-based fibers (without Se and S), the minimum of attenuation reported is $2.9 \mathrm{~dB} / \mathrm{m}$ at $10.2 \mu \mathrm{m}$. Recently, a promising method using plasma-enhanced chemical vapor deposition (PE-CVD) has been reported in a sulfur glass matrix [157]. However, this method has to be improved 
further in order to obtain lower optical losses. Indeed, this method has not yet achieved attenuation levels obtained for distillated glasses with chemical getters.

The common geometry of the chalcogenide fibers is the classical step index design (Figure 7a). Two methods can be used to fabricate such fibers: the rod-in-tube technique and the double crucible method [158-160]. The double crucible method is well adapted for drawing soft glass materials, such as chalcogenide glasses. This technique yields a high quality core-clad interface. One can note that the double crucible method is used for the fabrication of commercial step index chalcogenide fibers $[161,162]$. Because the fiber is drawn from the melt, this drawing method can be only used for glass compositions that exhibit a low tendency to crystallize. Chalcogenide fibers can also be drawn from a preform. This technique, called rod-in-tube, permits the realization of step index fibers $[163,164]$. In this case, a small rod of the core composition is placed into a clad tube and drawn together while applying a small negative pressure between the core and the clad in order to collapse any gap between the two glasses. With the rod-in-tube, method it is easier to control the size of the fiber-core and more particularly the core-clad ratio. However, with the rod-in-tube technique, any defects located at the core-clad interface induce additional optical losses due to scattering. As an example, the minimum of attenuation obtained with the double crucible technique is $12 \mathrm{~dB} / \mathrm{km}$, where the minimum of attenuation obtained with the rod in tube technique is more than $5 \mathrm{~dB} / \mathrm{m}$ [165]. In order to improve the quality of interface between the core and the clad, chalcogenide preforms made by extrusion have been investigated that can permit reducing the scattering loss to around $1-2 \mathrm{~dB} / \mathrm{m}[94,166]$. However, the optical losses are still higher than the optical loss obtained by the double crucible method.

In the 1990s, a new type of fiber, the microstructured optical fiber (MOF), attracted much interest $[167,168]$. Since then, this new fiber design has been made using many glasses and, since 2000, has been extended to chalcogenide glasses $[169,170]$. Here, the interest is to combine the properties of microstructured fibers with those of chalcogenide glasses (mid-infrared transmission and high nonlinear properties). In most cases, only one material is required to guarantee the light propagation in the core. The inclusions surrounding the core are generally filled with air. Contrary to the fabrication of standard fiber, there is no need to control precisely the index of refraction difference between core and cladding. This point is important because it offers the possibility to make MOFs based on glasses for which the control of refractive index is difficult to achieve. The guiding regime depends only on the geometric parameters of the hole diameter, $d$, and the distance between the holes, $\Lambda$. When the $\mathrm{d} / \Lambda$ ratio is smaller than 0.42 , the fiber is single-mode regardless of wavelength and this guiding regime is often called the "endlessly single-mode" regime [171,172]. A small-core diameter can be achieved, which is an advantage for enhancing the nonlinear effects. Furthermore, the zero-dispersion wavelength (ZDW) can be controlled over a wider range of wavelengths. On the contrary, large-core diameters can be obtained to reduce thermal and nonlinear effects. Consequently, the transmitted power can be significantly increased. Figure $7 \mathrm{~b}, \mathrm{c}, \mathrm{d}$ shows examples of original designs obtained with chalcogenide glass compositions. The fiber illustrated in Figure $7 \mathrm{~b}$ is an example of the three rings of a hole fiber with a $\mathrm{d} / \Lambda$ ratio lower than 0.42 and then exhibiting an endlessly single-mode behavior [165]. The fiber presented in Figure 7c is an exposed core fiber, which is very sensitive to the environment and can be used as an infrared sensor [173]. The last fiber presented in Figure 7d is a hollow core fiber. This design permits light to propagate in the air core of the fiber, such that the mid-infrared wavelength can be carried at wavelengths that are beyond the multiphonon cutting edge of a classical solid core fiber [174]. The common method for the fabrication of microstructured fibers is the stack and draw method [167]. The drilling method, where the preform is obtained by drilling several holes in a glass rod, or the molding method, where the chalcogenide glass is flown down in a silica mold, is an original process that can permit obtaining monolithic preforms and after drawing microstructured optical fibers [175-177]. 


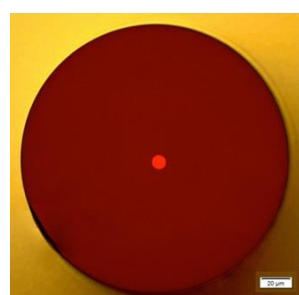

(a)

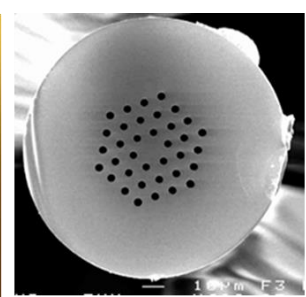

(b)

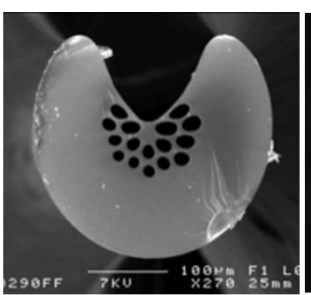

(c)

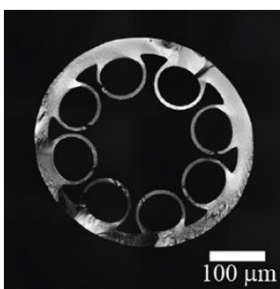

(d)

Figure 7. Chalcogenide fiber designs: (a) Step index fiber (courtesy of IRflex); (b) Single-mode microstructured fiber (courtesy of SelenOptics); (c) Exposed core fiber, reproduced with permission from [173], copyright Elsevier, 2013; (d) Hollow core fiber, reproduced with permission from [174], copyright OSA, 2016.

Due to their mid-IR optical transparency, chalcogenide glasses and, more particularly, chalcogenide fibers are good candidates for the development of optical sensors. Indeed, chalcogenide fibers are suitable for mid-IR sensors based on the fiber evanescent wave spectroscopy (FEWS) method [178] (Figure 8).

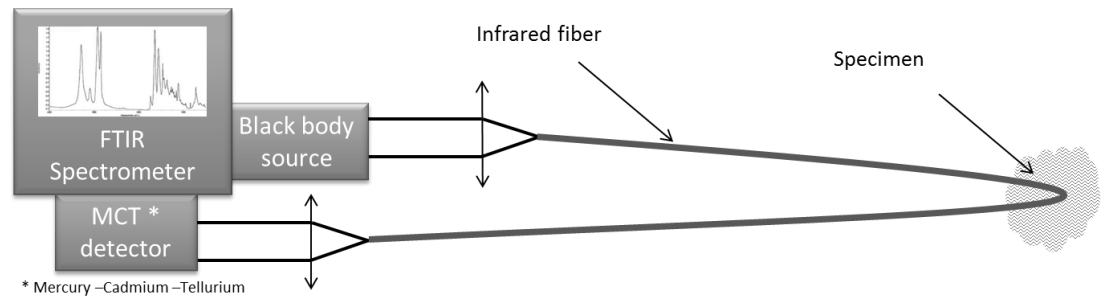

Figure 8. Principle of the fiber evanescent wave spectroscopy. The infrared light is focused at the input of the fiber and collected by the detector. The infrared signature of the analyzed specimen is recorded by applying it on the surface of the fiber.

The principle of the FEWS method can be compared to the attenuated total reflection (ATR) spectroscopy. In an optical fiber, the light propagates by total internal reflection. When a sensate is in contact with the surface of a chalcogenide fiber, the evanescent wave can be partially absorbed. The optical signature of the sensate will be observed at the output of the fiber (Figure 8). The first experiments using chalcogenide fibers have reported the detection of different chemical substances, such as butanone, acetone and ethanol [178]. Later, the chalcogenide fiber has been used in more complex media, in order to achieve environmental and biomedical purposes. Often used with liquids, the FEWS method can be also used for tissue analysis [179] and gas analysis [180]. Before 2014, all of the fibers used were selenide based. With selenide fibers, the longer wavelengths that can be detected are around 11-12 $\mu \mathrm{m}$. Indeed, as illustrated in Figure 6, the attenuation losses of selenide-based fibers such as $\mathrm{As}_{40} \mathrm{Se}_{60}$ fiber or $\mathrm{As}_{20} \mathrm{Te}_{30} \mathrm{Se}_{50}$ fiber are too strong for wavelengths longer than $11 \mu \mathrm{m}$.

In order to detect IR signatures beyond $12 \mu \mathrm{m}$, tellurium-based chalcogenide fibers were developed. As an example, FEWS experiments performed using a Ga-Te-AgI fiber permit the observation of the mid-IR signature of $\mathrm{CCl}_{4}$ at $16 \mu \mathrm{m}$, which is not possible in a classical selenide-based chalcogenide fiber [151].

As discussed, the main applications of chalcogenide fibers are mid-IR spectroscopy and analysis. Recently, the chalcogenide fibers used for such applications were found to be also biocompatible [181]. Despite their low glass transition temperatures, the chalcogenide glasses were found to be chemically stable: they are not soluble in water, but slightly soluble in alkaline and acid solutions [182]. The optical properties of these fibers were found to be unaltered after extended storage or even after immersion in water despite surface oxidation or surface pitting. The oxidation process was found to progress slowly and to be limited to a few nanometers. 
However, one can note that broadband and/or high intensity sources and lasers are missing the mid-IR region. Finally, the classical mid-IR sources are black-body radiation sources, which are for example the infrared sources of the FTIR spectrometers (Fourier transform infrared spectrometers). IR lasers in the 2-12 $\mu \mathrm{m}$ are not so common. However, several solid state lasers and gas lasers can emit in the mid-infrared. Rare-earth-doped lasers, quantum cascade lasers (QCL) and optical parametric sources are examples that can be achieved in the mid-infrared range [183]. None of these examples are fiber based, and there are not presently any fiber lasers that emits at wavelengths beyond $4.5 \mu \mathrm{m}$ [184]. In this context, strong interest for compact and intense mid-IR fiber laser are emerging. Again, due to their mid-IR transparency, the chalcogenide fibers are good candidates for the development of a new generation of mid-IR sources. Two different approaches being investigated include: rare-earth doping and nonlinear supercontinuum generation.

Mid-IR fluorescence can be obtained by doping and/or codoping a chalcogenide glass with luminescent rare-earth (RE) ions, such as $\mathrm{Er}^{3+}, \mathrm{Pr}^{3+}, \mathrm{Nd}^{3+}, \mathrm{Tb}^{3+}, \mathrm{Dy}^{3+}$ and $\mathrm{Ho}^{3+}$ [185-189]. The low phonon energy exhibited by the chalcogenide glass matrix permits mid-IR transmission beyond $10 \mu \mathrm{m}$. Furthermore, the low phonon energy of the network formers enhances the rare-earth emission efficiency and provides emission properties that typically are quenched in oxide glasses. The first chalcogenide used for hosting rare-earths was $\mathrm{As}_{2} \mathrm{~S}_{3}$ glass [185]. In order to increase the RE concentration that can be added into a chalcogenide glass, the glass network has to be modified. For this reason, new compositions with the addition of gallium (or indium) have been developed and investigated. Ga-La-S [188] and Ge-Ge-Sb-S (Se) $[186,190]$ are examples of glass matrices that can host several thousand ppm of RE doping. Among the different RE ions, the most studied ions are $\mathrm{Dy}^{3+}$ and $\mathrm{Pr}^{3+}$. The $\mathrm{Dy}^{3+}$ ion exhibits two mid-IR emissions centered at $2.9 \mu \mathrm{m}$ and $4.3 \mu \mathrm{m}$ [190]. With $\mathrm{Pr}^{3+}$ ions, broad IR emissions from $3.5 \mu \mathrm{m}-5 \mu \mathrm{m}$, with a maximum at $4.7 \mu \mathrm{m}$, have been studied [186]. In [190], the broad fluorescence from $3.5 \mu \mathrm{m}-4.7 \mu \mathrm{m}$ of $\mathrm{Dy}^{3+}$ chalcogenide-doped fibers has been used for detection on $\mathrm{CO}_{2}$ gas, which has a strong absorption band at $4.26 \mu \mathrm{m}$. In that study, the mid-IR fluorescence source obtained permits one to detect a concentration of $\mathrm{CO}_{2}$ down to a concentration of about 500 ppm.

A second approach to obtain new mid-IR sources is supercontinuum generation. A supercontinuum is a strong spectral broadening induced by successive nonlinear effects. The light propagation properties in fibers are well adapted to yield strong nonlinear effects. First observed in silica fibers [191], several studies have reported mid-IR supercontinuum generation in chalcogenide fibers [192-198]. Table 2 presents several supercontinuum results obtained in step index chalcogenide fibers or microstructured optical fibers.

Table 2. Examples of supercontinuum broadening obtained in chalcogenide optical fibers.

\begin{tabular}{ccccc}
\hline Fiber & Spectral Broadening & $\lambda_{\text {pump }}$ (Pulse Duration) & Average Power $(\mathbf{m W})$ & Reference \\
\hline As-S MOF ** & $1-4 \mu \mathrm{m}$ & $2.5 \mu \mathrm{m}(200 \mathrm{fs})$ & - & {$[194]$} \\
As-S SIF & $1.9-4,8 \mu \mathrm{m}$ & $2-2.4 \mu \mathrm{m}(>100 \mathrm{ps})$ & 565 & {$[193]$} \\
As-Se MOF & $1.7-7.5 \mu \mathrm{m}$ & $4.4 \mu \mathrm{m}(320 \mathrm{fs})$ & 15 & {$[196]$} \\
Ge-As-Se SIF & $1.8-10 \mu \mathrm{m}$ & $4 \mu \mathrm{m}(330 \mathrm{fs})$ & - & {$[195]$} \\
Ge-Sb-Se SIF & $2.2-12 \mu \mathrm{m}$ & $4.5 \mu \mathrm{m}(320 \mathrm{fs})$ & 17 & {$[198]$} \\
Ge-As-Se SIF * & $1.4-13.3 \mu \mathrm{m}$ & $4-7 \mu \mathrm{m}(100 \mathrm{fs})$ & 0,7 & {$[192]$} \\
As-Se SIF & $2-15 \mu \mathrm{m}$ & $9.8 \mu \mathrm{m}(170 \mathrm{fs})$ & - & {$[197]$} \\
\hline
\end{tabular}

*SIF: step index fiber; ** MOF: microstructured optical fibers.

The first supercontinua have been obtained as observed in sulfide-based fibers [193,194]. Later, in order to obtain supercontinuum beyond $5 \mu \mathrm{m}$, selenide-based fibers have been investigated. With selenide-based fibers, the supercontinuum can reach more than $12 \mu \mathrm{m}$. Mainly obtained in step index fibers, supercontinua generated in chalcogenide MOFs have been also reported $[194,196]$. As example, in [196], a spectral broadening from 1.7-7.5 with an average power of $15 \mathrm{~mW}$ has been obtained in suspended core As-Se fiber by pumping at $4.4 \mu \mathrm{m}$. 


\section{Conclusions and Future Opportunities}

Over the past decade, considerable progress has been achieved in the development of glasses and processes for the manufacture of advanced optical fibers. Given the material attributes, existing manufacturing infrastructure and commercial success of optical fibers, it is without question that work will continue to further improve fiber compositional and design flexibility, process simplicity, and the spectroscopic efficiencies of active fibers. Fabrication technologies for optical fibers are constantly evolving, driven by economic motives, and will favor the most cost-effective technologies for larger scale preforms.

Continued research into ND-doped and UPNC-doped tellurite glasses and fibers to date suggests that the direct doping method is a powerful technique to add NCs in a glass matrix. Future work is anticipated to comprise the use of other NCs and glasses to advance the understanding of the interaction of NCs with the glass matrix during the doping step to reveal the impact of NC and glass composition on the dissolution and dispersion of the NCs in a glass. Future NC-doped glasses and fibers with improved dispersion and enhanced control of dissolution are expected to pave the way for practical applications ranging from photonic sensor, photonic memory, single photon sources, to microcavity lasers, as well as full-color display systems. The direct doping method can be further investigated so that other NCs with photonic, electronic and magnetic properties of interest could be added, leveraging the performance and functions of the new NC-doped glasses and fibers enabled by the direct doping approach.

Areas of note for future research and development include continued efforts to realize fibers from new/different compositions (e.g., GaAs and other binary and ternary semiconductors; particularly ones exhibiting $\chi^{(2)}$ nonlinearities), tailoring of cladding glasses in order to better match semiconductor thermomechanical properties and IR transparency, single-mode fibers, possibly based on tapering, which exhibit enhanced nonlinearities, and novel in-fiber junction and photovoltaic devices. These seem particularly to be where the greatest value arises from the marriage of semiconductor physics and fiber optics. Lastly, the growing interest for the mid-IR wavelengths and mid-IR spectroscopy analysis will motivate and enhance the development of new mid-IR materials and fibers, such as chalcogenide glasses and fibers.

Acknowledgments: Laeticia Petit would like to acknowledge the financial support of the Academy of Finland through Competitive Funding to Strengthen University Research Profiles (310359).

Author Contributions: This article has been written by the stated authors (L.P.: silica-based optical fibers; H.E.-H. and J.Z.: nanoparticle-doped glasses and fibers; J.B.: semiconductor core optical fibers; and J.T.: innovative chalcogenide glasses and optical fibers), who are all aware of its content and approve its submission.

Conflicts of Interest: The authors declare no conflict of interest. The founding sponsors had no role in the design of the study; in the collection, analyses or interpretation of data; in the writing of the manuscript; nor in the decision to publish the results.

\section{References}

1. Osanai, H.; Shioda, T.; Moriyama, T.; Araki, S.; Horiguchi, M.; Izawa, T.; Takata, H. Effect of dopants on transmission loss of low-OH-content optical fibres. Electron. Lett. 1976, 12, 549-550. [CrossRef]

2. Saifi, M.A. Emerging applications of optical fibers and photonics in intelligent automobiles and highway systems. In Proceedings of the 8th Annual Meeting Conference on IEEE Lasers and Electro-Optics Society 1995 Annual Meeting, San Francisco, CA, USA, 30-31 October 1995; Volume 2, pp. 382-383.

3. Peterson, J.I.; Vurek, G.G. Fiber-Optic sensors for biomedical applications. Science 1984, 224, $123-127$. [CrossRef] [PubMed]

4. Bubnov, M.M.; Vechkanov, V.N.; Gur'yanov, A.N.; Zotov, K.V.; Lipatov, D.S.; Likhachev, M.E.; Yashkov, M.V. Fabrication and optical properties of fibers with an $\mathrm{Al}_{2} \mathrm{O}_{3}-\mathrm{P}_{2} \mathrm{O}_{5}-\mathrm{SiO}_{2}$ glass core. Inorg. Mater. 2009, 45, 444-449. [CrossRef]

5. Weber, M.J. Science and technology of laser glass. J. Non-Cryst. Solids 1990, 123, 208-222. [CrossRef]

6. Digonnet, M.J.F. Rare-Earth-Doped Fiber Lasers and Amplifiers; Marcel Dekker: New York, NY, USA, 2002. 
7. Likhachev, M.E.; Bubnov, M.M.; Zotov, K.V.; Medvedkov, O.I.; Lipatov, D.S.; Yashkov, M.V.; Guryanov, A.N. Erbium-doped aluminophosphosilicate optical fibres. Quantum Electron. 2010, 40, 633-638. [CrossRef]

8. DiGiovanni, D.J.; MacChesney, J.B.; Kometani, T.Y. Structure and properties of silica containing aluminum and phosphorus near the $\mathrm{AlPO}_{4}$ join. J. Non-Cryst. Solids 1989, 113, 58-64. [CrossRef]

9. Townsend, J.E.; Poole, S.B.; Payne, D.N. Solution-doping technique for fabrication of rare-earth-doped optical fibres. Electron. Lett. 1987, 23, 329-331. [CrossRef]

10. Nagel, S.R.; MacChesney, J.B.; Walker, K.L. An overview of the modified chemical vapor deposition (MCVD) process and performance. IEEE J. Quantum Electron. 1982, 18, 459-476. [CrossRef]

11. Barua, P.; Sekiya, E.H.; Saito, K.; Ikushima, A.J. Influences of $\mathrm{Yb}^{3+}$ ion concentration on the spectroscopic properties of silica glass. J. Non-Cryst. Solids 2008, 354, 4760-4764. [CrossRef]

12. Poole, S.B.; Payne, D.N.; Fermann, M.E. Fabrication of low-loss optical fibres containing rare-earth ions. Electron. Lett. 1985, 21, 737-738.

13. Sekiya, E.H.; Barua, P.; Saito, K.; Ikushima, A.J. Fabrication of Yb-doped silica glass through the modification of MCVD process. J. Non-Cryst. Solids 2008, 354, 4737-4742. [CrossRef]

14. Unger, S.; Lindner, F.; Aichele, C.; Leich, M.; Schwuchow, A.; Kobelke, J.; Dellith, J.; Schuster, K.; Bartelt, H. A highly efficient $\mathrm{Yb}$-doped silica laser fiber prepared by gas phase doping technology. Laser Phys. 2014, 24, 035103. [CrossRef]

15. Webb, A.S.; Boyland, A.J.; Standish, R.J.; Yoo, S.; Sahu, J.K.; Payne, D.N. MCVD in-situ solution doping process for the fabrication of complex design large core rare-earth doped fibers. J. Non-Cryst. Solids 2010, 356, 848-851. [CrossRef]

16. Boyland, A.J.; Webb, A.S.; Kalita, M.P.; Yoo, S.; Codemard, C.A.; Standish, R.J.; Nilsson, J.; Sahu, J.K. Rare-Earth Doped Optical Fiber Fabrication Using Novel Gas Phase Deposition Technique. In Proceedings of the Conference on Lasers and Electrooptics (CLEO) and Quantum Electronics and Laser Science Conference (QELS), San Jose, CA, USA, 16-21 May 2010.

17. Arai, K.; Namikawa, H.; Kumata, K.; Honda, T. Aluminum or phosphorous co-doping effects on the fluorescence and structural properties of neodymium-doped silica glass. J. Appl. Phys. 1986, 59, 3430-3436. [CrossRef]

18. Blanc, W.; Mauroy, V.; Nguyen, L.; Bhaktha, B.N.S.; Sebbah, P.; Pal, B.P.; Dussardier, B. Fabrication of Rare Earth-Doped Transparent Glass Ceramic Optical Fibers by Modified Chemical Vapor Deposition. J. Am. Ceram. Soc. 2010, 94, 2315-2318. [CrossRef]

19. Blanc, W.; Dussardier, B.; Monnom, G.; Peretti, R.; Jurdyc, A.-M.; Jacquier, B.; Foret, M.; Roberts, A. Erbium emission properties in nanostructured fibers. Appl. Opt. 2009, 48, G119-G124. [CrossRef] [PubMed]

20. Paul, M.C.; Bysakh, S.; Das, S.; Pal, M.; Bhadra, S.K.; Yoo, S.; Boyland, A.J.; Sahu, J.K. Nano-Engineered $\mathrm{Yb}_{2} \mathrm{O}_{3}$ Doped Optical Fiber: Fabrication, Material Characterizations, Spectroscopic Properties and Lasing Characteristics: A Review. Sci. Adv. Mater. 2012, 4, 292-321. [CrossRef]

21. Pastouret, A.; Gonnet, C.; Collet, C.; Cavani, O.; Burov, E.; Chaneac, C.; Carton, A.; Jolivet, J.-P. Nanoparticle doping process for improved fibre amplifiers and lasers. In Proceedings of the SPIE 7195 Fiber Lasers VI: Technology, Systems, and Applications, San Jose, CA, USA, 19 February 2009; Volume 7195, p. 71951X.

22. Lindstrom, T.; Garber, E.; Edmonson, D.; Hawkins, T.; Bass, M.; Ballato, J. Spectral engineering of optical fiber preforms through active nanoparticle doping. Opt. Mater. Express 2012, 2, 1520-1528. [CrossRef]

23. Vermillac, M.; Fneich, H.; Lupi, J.-F.; Tissot, J.-B.; Kucera, C.; Vennéguès, P.; Mehdi, A.; Neuville, D.; Ballato, J.; Blanc, W. Use of thulium-doped $\mathrm{LaF}_{3}: \mathrm{Tm}^{3+}$ nanoparticles to lower the phonon energy of the thulium's environment in silica-based optical fibres. Opt. Mater. 2017, submitted.

24. Koponen, J.; Petit, L.; Kokki, T.; Aallos, V.; Paul, J.; Ihalainen, H. Progress in Direct Nanoparticle Deposition (DND) for the development of the next generation fiber lasers. Opt. Eng. 2011, 50, 111605. [CrossRef]

25. Ye, C.; Koponen, J.; Aallos, V.; Petit, L.; Kimmelma, O.; Kokki, T. Measuring bend losses in large-mode-area fibers. In Proceedings of the SPIE 9344, Fiber Lasers XII: Technology, Systems, and Applications, San Francisco, CA, USA, 4 March 2015; p. 934425.

26. Ye, C.; Koponen, J.; Aallos, V.; Petit, L.; Kimmelma, O.; Kokki, T. Mode coupling in few-mode large-mode-area fibers. In Proceedings of the SPIE 8961, Fiber Lasers XI: Technology, Systems, and Applications, San Francisco, CA, USA, 7 March 2014; p. 201489612W. 
27. Dianov, E.M.; Golant, K.M.; Karpov, V.I.; Khrapko, R.R.; Kurkov, A.S.; Protopopov, V.N.; Semenov, S.L.; Shebuniaev, A.G. Application of reduced-pressure plasma CVD technology to the fabrication of Er-doped optical fibers. Opt. Mater. 1994, 3, 181-185. [CrossRef]

28. Bufetov, I.A.; Golant, K.M.; Firstov, S.V.; Kholodkov, A.V.; Shubin, A.V.; Dianov, E.M. Bismuth activated alumosilicate optical fibers fabricated by surface-plasma chemical vapor deposition technology. Appl. Opt. 2008, 47, 4940-4944. [CrossRef] [PubMed]

29. Savel'ev, E.A.; Golant, K.M. Influence of fusing on the uniformity of the distribution of $\mathrm{Yb}^{3+}$ ions and the formation of clusters in silica with phosphorus admixture synthesized by SPCVD. Opt. Mater. Express 2015, 5, 2337-2346. [CrossRef]

30. Golant, K.M.; Bazakutsa, A.P.; Butov, O.V.; Chamorovskij, Y.K.; Lanin, A.V.; Nikitov, S.A. Bismuth-activated Silica-core Fibres Fabricated by SPCVD. In Proceedings of the Conference: Optical Communication (ECOC), Torino, Italy, 9-13 September 2010.

31. Brevet Silitec $\mathrm{n}^{\circ} \mathrm{WO}$ 2005/102947 A1 (Carlos PEDRIDO Datwyler Fiber SA). Available online: https:/ / patentscope.wipo.int/search/en/detail.jsf?docId=WO2005102947 (accessed on 3 November 2005).

32. Langner, A.; Such, M.; Schötz, G.; Reichel, V.; Grimm, S.; Just, F.; Leich, M.; Kirchhof, J.; Wedel, B.; Köhler, G.; et al. Development, manufacturing and lasing behavior of $\mathrm{Yb}$-doped ultra large mode area fibers based on Yb-doped fused bulk silica. In Proceedings of the SPIE 7580, Fiber Lasers VII: Technology, Systems, and Applications, San Francisco, CA, USA, 17 February 2010; p. 75802X.

33. Schuster, K.; Unger, S.; Aichele, C.; Lindner, F.; Grimm, S.; Litzkendorf, D.; Kobelke, J.; Bierlich, J.; Wondraczek, K.; Bartelt, H. Material and technology trends in fiber optics. Adv. Opt. Technol. 2014, 3, 447-468. [CrossRef]

34. Leich, M.; Just, F.; Langner, A.; Such, M.; Schötz, G.; Eschrich, T.; Grimm, S. Highly efficient Yb-doped silica fibers prepared by powder sinter technology. Opt. Lett. 2011, 36, 1557-1559. [CrossRef] [PubMed]

35. Norin, L.; Vanin, E.; Soininen, P.; Putkonen, M. Atomic Layer Deposition as a New Method for Rare-Earth Doping of Optical Fibers. In Proceedings of the Conference on Lasers and Electrooptics (CLEO), Baltimore, MD, USA, 6-11 May 2007; p. CTuBB5.

36. Montiel Ponsoda, J.J.; Norin, L.; Ye, C.; Bosund, M.; Söderlund, M.J.; Tervonen, A.; Honkanen, S. Ytterbium-doped fibers fabricated with atomic layer deposition method. Opt. Express 2012, 25085-25095. [CrossRef] [PubMed]

37. Wen, J.; Wang, J.; Dong, Y.; Chen, N.; Luo, Y.; Peng, G.-D.; Pang, F.; Chen, Z.; Wang, T. Photoluminescence properties of Bi / Al-codoped silica optical fiber based on atomic layer deposition method. Appl. Surf. Sci. 2015, 349, 287-291. [CrossRef]

38. Nadort, A.; Zhao, J.; Goldys, E.M. Lanthanide upconversion luminescence at the nanoscale: Fundamentals and optical properties. Nanoscale 2016, 8, 13099-13130. [CrossRef] [PubMed]

39. Zhao, J.; Jin, D.; Schartner, E.P.; Lu, Y.; Liu, Y.; Zvyagin, A.V.; Zhang, L.; Dawes, J.M.; Xi, P.; Piper, J.A.; et al. Single-nanocrystal sensitivity achieved by enhanced upconversion luminescence. Nat. Nanotechnol. 2013, 8 , 729-734. [CrossRef] [PubMed]

40. Wang, J.; Deng, R.; MacDonald, M.A.; Chen, B.; Yuan, J.; Wang, F.; Chi, D.; Andy Hor, T.S.; Zhang, P.; Liu, G.; et al. Enhancing multiphoton upconversion through energy clustering at sublattice level. Nat. Mater. 2014, 13, 157-162. [CrossRef] [PubMed]

41. Zhou, B.; Shi, B.; Jin, D.; Liu, X. Controlling upconversion nanocrystals for emerging applications. Nat. Nanotechnol. 2015, 10, 924-936. [CrossRef] [PubMed]

42. Dong, H.; Du, S.-R.; Zheng, X.-Y.; Lyu, G.-M.; Sun, L.-D.; Li, L.-D.; Zhang, P.-Z.; Zhang, C.; Yan, C.-H. Lanthanide Nanoparticles: From Design toward Bioimaging and Therapy. Chem. Rev. 2015, 115, 10725-10815. [CrossRef] [PubMed]

43. Balasubramanian, G.; Chan, I.Y.; Kolesov, R.; Al-Hmoud, M.; Tisler, J.; Shin, C.; Kim, C.; Wojcik, A.; Hemmer, P.R.; Krueger, A.; et al. Nanoscale imaging magnetometry with diamond spins under ambient conditions. Nature 2008, 455, 648-652. [CrossRef] [PubMed]

44. Taylor, J.M.; Cappellaro, P.; Childress, L.; Jiang, L.; Budker, D.; Hemmer, P.R.; Yacoby, A.; Walsworth, R.; Lukin, M.D. High-sensitivity diamond magnetometer with nanoscale resolution. Nat. Phys. 2008, 4, 810-816. [CrossRef] 
45. Dolde, F.; Fedder, H.; Doherty, M.W.; Nöbauer, T.; Rempp, F.; Balasubramanian, G.; Wolf, T.; Reinhard, R.; Hollenberg, L.C.L.; Jelezko, F.; et al. Electric-field sensing using single diamond spins. Nat. Phys. 2011, 7, 459-463. [CrossRef]

46. McGuinness, L.P.; Hall, L.T.; Stacey, A.; Simpson, D.A.; Hill, C.D.; Cole, J.H.; Ganesan, K.; Gibson, B.C.; Prawer, S.; Mulvaney, P.; et al. Ambient nanoscale sensing with single spins using quantum decoherence. New J. Phys. 2013, 15, 073042. [CrossRef]

47. Dejneka, M.J. Transparent oxyfluoride glass ceramics. MRS Bull. 1998, 23, 57-62. [CrossRef]

48. Herrmann, A.; Tylkowski, M.; Bocker, C.; Rüssel, C. Cubic and Hexagonal NaGdF 4 Crystals Precipitated from an Aluminosilicate Glass: Preparation and Luminescence Properties. Chem. Mater. 2013, 25, 2878-2884. [CrossRef]

49. Xiaoying, S.; Ping, C.; Wenjing, C.; Kan, Z.; Jing, M.; Donghai, F.; Shian, Z.; Zhenrong, S.; Jianrong, Q.; Tianqing, J. Fine tunable red-green upconversion luminescence from glass ceramic containing $5 \% \mathrm{Er}^{3+}: \mathrm{NaYF}_{4}$ nanocrystals under excitation of two near infrared femtosecond lasers. J. Appl. Phys. 2014, 116, 063101.

50. Melekhin, V.G.; Kolobkova, E.V.; Lipovskii, A.A.; Petrikov, V.D.; Malyarevich, A.M.; Savitsky, V.G. Fluorophosphate glasses doped with PbSe quantum dots and their nonlinear optical characteristics. Glass Phys. Chem. 2008, 34, 351-355. [CrossRef]

51. Masai, H.; Takahashi, Y.; Fujiwara, T. Glass-Ceramics Containing Nano-Crystallites of Oxide Semiconductor; Ceramic Materials; Wilfried Wunderlich, Ed.; Sciyo: Rijeka, Croatia, 2010.

52. Mattarelli, M.; Gasperi, G.; Montagna, M.; Verrocchio, P. Transparency and long-ranged fluctuations: The case of glass ceramics. Phys. Rev. B 2010, 82, 094204. [CrossRef]

53. Ledemi, Y.; Trudel, A.-A.; Rivera, V.A.G.; Chenu, S.; Veron, E.; Nunes, L.A.; Allix, M.; Messaddeq, Y. White light and multicolor emission tuning in triply doped $\mathrm{Yb}^{3+} / \mathrm{Tm}^{3+} / \mathrm{Er}^{3+}$ novel fluoro-phosphate transparent glass-ceramics. J. Mater. Chem. C 2014, 2, 5046-5056. [CrossRef]

54. Wang, Y.; Ohwaki, J. New transparent vitroceramics codoped with $\mathrm{Er}^{3+}$ and $\mathrm{Yb}^{3+}$ for efficient frequency upconversion. Appl. Phys. Lett. 1993, 63, 3268-3270. [CrossRef]

55. Chen, D.; Wang, Y.; Yu, Y.; Huang, P.; Weng, F. Near-infrared quantum cutting in transparent nanostructured glass ceramics. Opt. Lett. 2008, 33, 1884-1886. [CrossRef] [PubMed]

56. Dong, H.; Sun, L.-D.; Wang, Y.-F.; Ke, J.; Si, R.; Xiao, J.-W.; Lyu, G.-M.; Shi, S.; Yan, C.-H. Efficient Tailoring of Upconversion Selectivity by Engineering Local Structure of Lanthanides in $\mathrm{Na}_{x} \mathrm{REF}_{3+\mathrm{x}}$ Nanocrystals. J. Am. Chem. Soc. 2015, 137, 6569-6576. [CrossRef] [PubMed]

57. Zhang, Y.; Zhang, L.; Deng, R.; Tian, J.; Zong, Y.; Jin, D.; Liu, X. Multicolor Barcoding in a Single Upconversion Crystal. J. Am. Chem. Soc. 2014, 136, 4893-4896. [CrossRef] [PubMed]

58. Reineck, P.; Gibson, B.C. Near-Infrared Fluorescent Nanomaterials for Bioimaging and Sensing. Adv. Opt. Mater. 2016. [CrossRef]

59. Reineck, P.; Francis, A.; Orth, A.; Lau, D.W.M.; Nixon-Luke, R.D.V.; Rastogi, I.D.; Razali, W.A.W.; Cordina, N.M.; Parker, L.M.; Sreenivasan, V.K.A.; et al. Brightness and Photostability of Emerging Red and Near-IR Fluorescent Nanomaterials for Bioimaging. Adv. Opt. Mater. 2016, 4, 1549-1557. [CrossRef]

60. Mochalin, V.N.; Shenderova, O.; Ho, D.; Gogotsi, Y. The properties and applications of nanodiamonds. Nat. Nanotechnol. 2012, 7, 11-23. [CrossRef] [PubMed]

61. Jha, A.; Richards, B.; Jose, G.; Teddy-Fernandez, T.; Joshi, P.; Jiang, X.; Lousteau, J. Rare-earth ion doped $\mathrm{TeO}_{2}$ and $\mathrm{GeO}_{2}$ glasses as laser materials. Progress Mater. Sci. 2012, 57, 1426-1491. [CrossRef]

62. Jha, A.; Shen, S.; Naftaly, M. Structural origin of spectral broadening of 1.5- $\mu \mathrm{m}$ emission in $\mathrm{Er}^{3+}$-doped tellurite glasses. Phys. Rev. B 2000, 62, 6215-6227. [CrossRef]

63. Gao, G.; Winterstein-Beckmann, A.; Surzhenko, O.; Dubs, C.; Dellith, J.; Schmidt, M.A.; Wondraczek, L. Faraday rotation and photoluminescence in heavily $\mathrm{Tb}^{3+}$-doped $\mathrm{GeO}_{2}-\mathrm{B}_{2} \mathrm{O}_{3}-\mathrm{Al}_{2} \mathrm{O}_{3}-\mathrm{Ga}_{2} \mathrm{O}_{3}$ glasses for fiber-integrated magneto-optics. Sci. Rep. 2015, 5, 8942. [CrossRef] [PubMed]

64. Jiang, N.; Zhou, S.; Su, D.; Qiu, J. Do Eu dopants prefer the precipitated $\mathrm{LaF}_{3}$ nanocrystals in glass ceramics? Phys. Status Solidi (RRL) Rapid Res. Lett. 2012, 6, 487-489. [CrossRef]

65. De Pablos-Martin, A.; Patzig, C.; Höche, T.; Duran, A.; Pascual, M. Distribution of thulium in Tm ${ }^{3+}$-doped oxyfluoride glasses and glass-ceramics. CrystEngComm 2013, 15, 6979-6985. [CrossRef]

66. De Pablos-Martín, A.; García, M.A.; Muñoz-Noval, A.; Castro, G.R.; Pascual, M.J.; Durán, A. Analysis of the distribution of $\mathrm{Tm}^{3+}$ ions in $\mathrm{LaF}_{3}$ containing transparent glass-ceramics through X-ray absorption spectroscopy. J. Non-Cryst. Solids 2014, 384, 83-87. [CrossRef] 
67. Tick, P.A.; Borrelli, N.F.; Cornelius, L.K.; Newhouse, M.A. Transparent glass ceramics for $1300 \mathrm{~nm}$ amplifier applications. J. Appl. Phys. 1995, 78, 6367-6374. [CrossRef]

68. Hendy, S. Light scattering in transparent glass ceramics. Appl. Phys. Lett. 2002, 81, 1171-1173. [CrossRef]

69. Liu, C.; Heo, J. Lead Chalcogenide Quantum Dot-Doped Glasses for Photonic Devices. Int. J. Appl. Glass Sci. 2013, 4, 163-173. [CrossRef]

70. Samson, B.N.; Tick, P.A.; Borrelli, N.F. Efficient neodymium-doped glass-ceramic fiber laser and amplifier. Opt. Lett. 2001, 26, 145-147. [CrossRef] [PubMed]

71. Samson, B.N.; Pinckney, L.R.; Wang, J.; Beall, G.H.; Borrelli, N.F. Nickel-doped nanocrystalline glass-ceramic fiber. Opt. Lett. 2002, 27, 1309-1311. [CrossRef] [PubMed]

72. Zhao, J.; Lu, Z.; Yin, Y.; McRae, C.; Piper, J.A.; Dawes, J.M.; Jin, D.; Goldys, E.M. Upconversion luminescence with tunable lifetime in NaYF4:Yb,Er nanocrystals: role of nanocrystal size. Nanoscale. 2013, 5, 944-952. [CrossRef] [PubMed]

73. Gargas, D.J.; Chan, E.M.; Ostrowski, A.D.; Aloni, S.; Altoe, M.V.P.; Barnard, E.S.; Sanii, B.; Urban, J.J.; Milliron, D.J.; Cohen, B.E.; Schuck, P.J. Engineering bright sub-10-nm upconverting nanocrystals for single-molecule imaging. Nat. Nanotechnol. 2014, 9, 300-305. [CrossRef] [PubMed]

74. Liu, D.; Xu, X.; Du, Y.; Qin, X.; Zhang, Y.; Ma, C.; Wen, S.; Ren, W.; Goldys, E.M.; Piper, J.A. Three-dimensional controlled growth of monodisperse sub-50 nm heterogeneous nanocrystals. Nat. Commun. 2016, 7, 10254. [CrossRef] [PubMed]

75. Edmonds, A.M.; Sobhan, M.A.; Sreenivasan, V.K.A.; Grebenik, E.A.; Rabeau, J.R.; Goldys, E.M.; Zvyagin, A.V. Nano-Ruby: A Promising Fluorescent Probe for Background-Free Cellular Imaging. Part. Part. Syst. Charact. 2013, 30, 506-513. [CrossRef]

76. Gajc, M.; Surma, H.B.; Klos, A.; Sadecka, K.; Orlinski, K.; Nikolaenko, A.E.; Zdunek, K.; Pawlak, D.A. Nanoparticle Direct Doping: Novel Method for Manufacturing Three-Dimensional Bulk Plasmonic Nanocomposites. Adv. Funct. Mater. 2013, 23, 3443-3451. [CrossRef]

77. Karaksina, E.V.; Shiryaev, V.S.; Ketkova, L.A. Preparation of composite materials for fiber optics based on chalcogenide glasses containing ZnS(ZnSe):Cr(2+ $2^{+}$crystals. J. Non-Cryst. Solids 2013, 377, 220-224. [CrossRef]

78. Zhou, Y.; Chen, D.; Tian, W.; Ji, Z. Impact of Eu ${ }^{3+}$ Dopants on Optical Spectroscopy of $\mathrm{Ce}^{3+}: \mathrm{Y}_{3} \mathrm{Al}_{5} \mathrm{O}_{12^{-}}$ Embedded Transparent Glass-Ceramics. J. Am. Ceram. Soc. 2015, 2445-2450. [CrossRef]

79. Huang, J.; Hu, X.; Shen, J.; Wu, D.; Yin, C.; Xiang, R.; Yang, C.; Liang, X.; Xiang, W. Facile synthesis of a thermally stable $\mathrm{Ce}^{3+}: \mathrm{Y}_{3} \mathrm{Al}_{5} \mathrm{O}_{12}$ phosphor-in-glass for white LEDs. CrystEngComm 2015, 17, 7079-7085. [CrossRef]

80. Chai, G.; Dong, G.; Qiu, J.; Zhang, Q.; Yang, Z. $2.7 \mu \mathrm{m}$ Emission from Transparent $\mathrm{Er}^{3+}, \mathrm{Tm}^{3+}$ Codoped Yttrium Aluminum Garnet $\left(\mathrm{Y}_{3} \mathrm{Al}_{5} \mathrm{O}_{12}\right)$ Nanocrystals-Tellurate Glass Composites by Novel Comelting Technology. J. Phys. Chem. C 2012, 116, 19941-19950. [CrossRef]

81. Massera, J.; Gaussiran, M.; Głuchowski, P.; Lastusaari, M.; Rodrigues, L.C.V.; Petit, L.; Hölsä, J.; Hupa, L. Effect of the glass melting condition on the processing of phosphate-based glass-ceramics with persistent luminescence properties. Opt. Mater. 2016, 52, 56-61. [CrossRef]

82. Massera, J.; Głuchowski, P.; Lastusaari, M.; Rodrigues, L.C.V.; Petit, L.; Hölsä, J.; Hupa, L.; Hupa, M. New alternative route for the preparation of phosphate glasses with persistent luminescence properties. J. Eur. Ceram. Soc. 2015, 35, 1255-1261. [CrossRef]

83. Massera, J.; Petit, L.; Koponen, J.; Glorieux, B.; Hupa, L.; Hupa, M. $\mathrm{Er}^{3+}-\mathrm{Al}_{2} \mathrm{O}_{3}$ nanoparticles doping of borosilicate glass. Bull. Mater. Sci. 2015, 38, 1407-1410. [CrossRef]

84. Henderson, M.R.; Gibson, B.C.; Ebendorff-Heidepriem, H.; Kuan, K.; Afshar, V.S.; Orwa, J.O.; Aharonovich, I.; Tomljenovic-Hanic, S.; Greentree, A.D.; Prawer, S.; et al. Diamond in Tellurite Glass: A New Medium for Quantum Information. Adv. Mater. 2011, 23, 2806-2810. [CrossRef] [PubMed]

85. Ebendorff-Heidepriem, H.; Ruan, Y.; Ji, H.; Greentree, A.D.; Gibson, B.C.; Monro, T.M. Nanodiamond in tellurite glass Part I: Origin of loss in nanodiamond-doped glass. Opt. Mater. Express 2014, 4, 2608-2620. [CrossRef]

86. Ruan, Y.; Ji, H.; Johnson, B.C.; Ohshima, T.; Greentree, A.D.; Gibson, B.C.; Monro, T.M.; Ebendorff-Heidepriem, H. Nanodiamond in tellurite glass Part II: Practical nanodiamond-doped fibers. Opt. Mater. Express 2015, 5, $73-87$. [CrossRef] 
87. Zhao, J.; Zheng, X.; Schartner, E.P.; Ionescu, P.; Zhang, R.; Nguyen, T.-L.; Jin, D.; Ebendorff-Heidepriem, H. Upconversion Nanocrystals Doped Glass: A New Paradigm for Photonic Materials. Adv. Opt. Mater. 2016, 4, 1507-1517. [CrossRef]

88. Jalali, B.; Fathpour, S. Silicon photonics. J. Lightwave Technol. 2006, 24, 4600-4615. [CrossRef]

89. Leuthold, J.; Koos, C.; Freude, W. Nonlinear silicon photonics. Nat. Photonics 2010, 4, 535-544. [CrossRef]

90. Ballato, J.; Hawkins, T.; Foy, P.; Yazgan-Kokuoz, B.; McMillen, C.; Burka, L.; Morris, S.; Stolen, R.; Rice, R. Advancements in Semiconductor Core Optical Fiber. Opt. Fiber Technol. 2010, 16, 399-408. [CrossRef]

91. Morris, S.; Ballato, J. Molten Core Fabrication of Novel Optical Fibers. Bull. Am. Ceram. Soc. 2013, 92, $24-29$.

92. Ballato, J.; Dragic, P. Rethinking Optical Fiber: New Demands, Old Glasses. J. Am. Ceram. Soc. 2013, 96, 2675-2692. [CrossRef]

93. Peacock, A.; Sparks, J.; Healy, N. Semiconductor optical fibres: Progress and opportunities. Laser Photonics Rev. 2014, 8, 53-72. [CrossRef]

94. Tao, G.; Ebendorff-Heidepriem, H.; Stolyarov, A.; Danto, S.; Badding, J.; Fink, Y.; Ballato, J.; Abouraddy, A. Infrared fibers. Adv. Opt. Photonics 2015, 7, 379-458. [CrossRef]

95. Peacock, A.; Gibson, U.; Ballato, J. Silicon Optical Fiber-Past, Present, and Future. Adv. Phys. X 2016, 1, 114-127.

96. Sparks, J.; Sazio, P.; Gopalan, V.; Badding, J. Templated Chemically Deposited Semiconductor Optical Fiber Materials. Ann. Rev. Mater. Res. 2013, 43, 527-557. [CrossRef]

97. Shimamura, K.; Uda, S.; Yamada, T.; Sakaguchi, S.; Fukuda, T. Silicon single crystal fiber growth by micro pulling down method. Jpn. J. Appl. Phys. 1996, 35, L793-L795. [CrossRef]

98. Sazio, P.; Amezcua-Correa, A.; Finlayson, C.; Hayes, J.; Scheidemantel, T.; Baril, N.; Jackson, B.; Won, D.; Zhang, F.; Margine, E.; et al. Microstructured optical fibers as high-pressure microfluidic reactors. Science 2006, 311, 1583-1586. [CrossRef] [PubMed]

99. Ballato, J.; Hawkins, T.; Foy, P.; Stolen, R.; Kokuoz, B.; Ellison, M.; McMillen, C.; Reppert, J.; Rao, A.; Daw, M.; et al. Silicon Optical Fiber. Opt. Express 2008, 16, 18675-18683. [CrossRef] [PubMed]

100. Ballato, J.; Snitzer, E. Fabrication of Fibers with High Rare-Earth Concentrations for Faraday Isolator Applications. Appl. Opt. 1995, 34, 6848-6854. [CrossRef] [PubMed]

101. Scott, B.; Ke, W.; Pickrell, G. Fabrication of n-Type Silicon Optical Fibers. Photon Technol. Lett. 2009, 21, 1798-1800. [CrossRef]

102. Finlayson, C.; Amezcua-Correa, A.; Sazio, P.; Baril, N.; Badding, J. Electrical and Raman characterization of silicon and germanium-filled microstructured optical fibers. Appl. Phys. Lett. 2007, 90, 132110. [CrossRef]

103. Ballato, J.; Hawkins, T.; Foy, P.; Yazgan-Kokuoz, B.; Stolen, R.; McMillen, C.; Hon, N.; Jalali, B.; Rice, R. Glass-Clad Single-Crystal Germanium Optical Fiber. Opt. Express 2009, 17, 8029-8035. [CrossRef] [PubMed]

104. Ballato, J.; Hawkins, T.; Foy, P.; Morris, S.; Hon, N.; Jalali, B.; Rice, R. Silica-Clad Crystalline Germanium Core Optical Fiber. Opt. Lett. 2011, 36, 687-688. [CrossRef] [PubMed]

105. Deng, D.; Orf, N.; Danto, S.; Abouraddy, A.; Joannopoulos, J.; Fink, Y. Processing and properties of centimeter-long, in-fiber, crystalline-selenium filaments. Appl. Phys. Lett. 2010, 96, 023102. [CrossRef]

106. Tang, G.; Qian, Q.; Wen, X.; Zhou, G.; Chen, X.; Sun, M.; Chen, D.; Yang, Z. Phosphate glass-clad tellurium semiconductor core optical fibers. J. Alloys Compd. 2015, 633, 1-4. [CrossRef]

107. Coucheron, D.; Fokine, M.; Patel, N.; Breiby, D.; Tore Buset, O.; Hawkins, T.; Jones, M.; Ballato, J.; Gibson, U. Laser inscription of compositional microstructures in crystalline SiGe-core fibres. Nat. Commun. 2017, in press. [CrossRef] [PubMed]

108. Tang, G.; Qian, Q.; Wen, X.; Chen, X.; Liu, W.; Sun, M.; Yang, Z. Reactive molten core fabrication of glass-clad $\mathrm{Se}_{0.8} \mathrm{Te}_{0.2}$ semiconductor core optical fibers. Opt. Express 2015, 23, 23624-23633. [CrossRef] [PubMed]

109. Ballato, J.; Hawkins, T.; Foy, P.; McMillen, C.; Burka, L.; Reppert, J.; Podila, R.; Rao, A.; Rice, R. Binary III-V Semiconductor Core Optical Fiber. Opt. Express 2010, 18, 4972-4979. [CrossRef] [PubMed]

110. Sparks, J.; He, R.; Healy, N.; Krishnamurthi, M.; Peacock, A.; Sazio, P.; Gopalan, V.; Badding, J. Zinc selenide optical fibers. Adv. Mater. 2011, 23, 1647-1651. [CrossRef] [PubMed]

111. Hou, C.; Jia, X.; Wei, L.; Stolyarov, A.; Shapira, O.; Joannopoulos, J.; Fink, Y. Direct atomic-level observation and chemical analysis of ZnSe synthesized by in situ high-throughput reactive fiber drawing. Nano Lett. 2013, 13, 975-979. [CrossRef] [PubMed]

112. Morris, S.; Martin, S.; Hawkins, T.; Foy, P.; Rice, R.; Ballato, J. Cladding Glass Development for Semiconductor Core Optical Fibers. Int. J. Appl. Glass. Sci. 2012, 3, 144-153. [CrossRef] 
113. Orf, N.; Shapira, O.; Sorin, F.; Danto, S.; Baldo, M.; Joannopoulos, J.; Fink, Y. Fiber draw synthesis. Proc. Nat. Acad. Sci. USA 2011, 108, 4743-4747. [CrossRef]

114. Hou, C.; Jia, X.; Wei, L.; Tan, S.; Zhao, X.; Joannopoulos, J.; Fink, Y. Crystalline silicon core fibres from aluminium core preforms. Nat. Commun. 2015, 6, 6248. [CrossRef] [PubMed]

115. Healy, N.; Lagonigro, L.; Sparks, J.; Boden, S.; Sazio, P.; Badding, J.; Peacock, A. Polycrystalline silicon optical fibers with atomically smooth surfaces. Opt. Lett. 2011, 36, 2480-2482. [CrossRef] [PubMed]

116. Morris, S.; Hawkins, T.; Foy, P.; Hudson, J.; Zhu, L.; Stolen, R.; Ballato, J. On loss in silicon core optical fibers. Opt. Mater. Express 2012, 2, 1511-1519. [CrossRef]

117. Scott, B.; Pickrell, G. Silicon optical fiber diameter dependent grain size. J. Cryst. Growth 2013, 371, $134-141$. [CrossRef]

118. Morris, S.; Hawkins, T.; Foy, P.; McMillen, C.; Fan, J.; Zhu, L.; Stolen, R.; Rice, R.; Ballato, J. Reactive Molten Core Fabrication of Silicon Optical Fiber. Opt. Mater. Express 2011, 1, 1141-1149. [CrossRef]

119. Nordstrand, E.; Dibbs, A.; Eraker, A.; Gibson, U. Alkaline oxide interface modifiers for silicon fiber production. Opt. Mater. Express 2013, 3, 651-657. [CrossRef]

120. McMillen, C.; Hawkins, T.; Foy, P.; Mulwee, D.; Kolis, J.; Rice, R.; Ballato, J. On Crystallographic Orientation in Crystal Core Optical Fibers. Opt. Mater. 2010, 32, 862-867. [CrossRef]

121. Gupta, N.; McMillen, C.; Singh, R.; Podila, R.; Rao, A.; Hawkins, T.; Foy, P.; Morris, S.; Rice, R.; Poole, K.; Zhu, L.; Ballato, J. Annealing of Silicon Optical Fibers. J. Appl. Phys. 2011, 110, 093107. [CrossRef]

122. Morris, S.; McMillen, C.; Hawkins, T.; Foy, P.; Stolen, R.; Rice, R.; Ballato, J. The Influence of Core Geometry on the Crystallography of Silicon Optical Fiber. J. Cryst. Growth 2012, 352, 53-58. [CrossRef]

123. McMillen, C.; Brambilla, G.; Morris, S.; Hawkins, T.; Foy, P.; Broderick, N.; Rice, R.; Ballato, J. On Crystallographic Orientation in Crystal Core Optical Fibers II: Effects of Tapering. Opt. Mater. 2012, 35, 93-96. [CrossRef]

124. Healy, N.; Mailis, S.; Bulgakova, N.; Sazio, P.; Day, T.; Sparks, J.; Cheng, H.; Badding, J.; Peacock, A. Extreme electronic bandgap modification in laser-crystallized silicon optical fibres. Nat. Mater. 2014, 13, 1122-1127. [CrossRef] [PubMed]

125. Coucheron, D.; Fokine, M.; Patil, N.; Breiby, D.; Buset, O.; Healy, N.; Peacock, A.; Hawkins, T.; Jones, M.; Ballato, J.; et al. $\mathrm{CO}_{2}$ Laser-Induced Directional Recrystallization to Produce Single Crystal Silicon-Core Optical Fibers with Low Loss. Adv. Opt. Mater. 2016, 4, 1004-1008.

126. Won, D.; Ramirez, M.; Kang, H.; Gopalan, V.; Baril, N.; Calkins, J.; Badding, J.; Sazio, P. All-optical modulation of laser light in amorphous silicon-filled microstructured optical fibers. Appl. Phys. Lett. 2007, 91, 161112. [CrossRef]

127. Mehta, P.; Healy, N.; Baril, N.; Sazio, P.; Badding, J.; Peacock, A. Nonlinear transmission properties of hydrogenated amorphous silicon core optical fibers. Opt. Express 2010, 18, 16826-16831. [CrossRef] [PubMed]

128. Mehta, P.; Healy, N.; Sparks, J.; Day, T.; Sazio, P.; Badding, J.; Peacock, A. All-optical modulation using two-photon absorption in silicon core optical fibers. Opt. Express 2011, 19, 19078-19083. [CrossRef] [PubMed]

129. Mehta, P.; Healy, N.; Day, T.; Badding, J.; Peacock, A. Ultrafast wavelength conversion via cross-phase modulation in hydrogenated amorphous silicon optical fibers. Opt. Express 2012, 20, 26110-26116. [CrossRef] [PubMed]

130. Shen, L.; Healy, N.; Xu, L.; Cheng, H.; Day, T.; Price, J.; Badding, J.; Peacock, P. Four-wave mixing and octave-spanning supercontinuum generation in a small core hydrogenated amorphous silicon fiber pumped in the mid-infrared. Opt. Lett. 2014, 39, 5721-5724. [CrossRef] [PubMed]

131. Peacock, A. Soliton propagation in tapered silicon core fibers. Opt. Lett. 2010, 35, 3697-3699. [CrossRef] [PubMed]

132. Suhailin, F.; Shen, L.; Healy, N.; Xiao, L.; Jones, M.; Hawkins, T.; Ballato, J.; Gibson, U.; Peacock, A. Tapered polysilicon core fibers for nonlinear photonics. Opt. Lett. 2016, 41, 1360-1363. [CrossRef] [PubMed]

133. Gumennik, A.; Wei, L.; Lestoquoy, G.; Stolyarov, A.; Jia, X.; Rekemeyer, P.; Smith, M.; Liang, X.; Grena, B.; Johnson, S.; et al. Silicon-in-silica spheres via axial thermal gradient in-fibre capillary instabilities. Nat. Commun. 2013, 4, 2216-2220. [CrossRef] [PubMed]

134. Wang, P.; Lee, T.; Ding, M.; Dhar, A.; Hawkins, T.; Foy, P.; Semenova, Y.; Wu, Q.; Sahu, J.; Farrell, G.; et al. A Germanium Microsphere High-Q Resonator. Opt. Lett. 2012, 37, 728-730. [CrossRef] [PubMed]

135. Lin, C.; Chen, J.; Wang, L. High-Q Si microsphere resonators fabricated from Si-cored fibers for WGMs excitation. IEEE Photonics Technol. Lett. 2015, 27, 1355-1358. [CrossRef] 
136. Vukovic, N.; Healy, N.; Day, T.; Sparks, J.; Saizo, P.; Badding, J.; Peacock, A. Thermal nonlinearity in silicon microcylindrical resonators. Appl. Phys. Lett. 2012, 100, 181101. [CrossRef]

137. Vukovic, N.; Healy, N.; Suhailin, F.; Mehta, P.; Day, T.; Badding, J.; Peacock, A. Ultrafast optical control using the Kerr nonlinearity in hydrogenated amorphous silicon microcylindrical resonators. Sci. Rep. 2013, 3, 2885. [CrossRef] [PubMed]

138. Suhailin, F.; Healy, N.; Franz, Y.; Sumetsky, M.; Ballato, J.; Dibbs, A.; Gibson, U.; Peacock, A. Kerr nonlinear switching in a hybrid silica-silicon microspherical resonator. Opt. Express 2015, 23, 17263-17268. [CrossRef] [PubMed]

139. Healy, N.; Sparks, J.; He, R.; Sazio, P.; Badding, J.; Peacock, A. High index contrast semiconductor ARROW and hybrid ARROW fibers. Opt. Express 2011, 19, 10979-10985. [CrossRef] [PubMed]

140. Wang, P.; Charlton, C.; Lee, T.; Ismaeel, R.; Hawkins, T.; Semenova, Y.; Bo, L.; Wu, Q.; McDonagh, C.; Farrell, G.; et al. Mid-infrared Raman sources using spontaneous Raman scattering in germanium core optical fibers. Appl. Phys. Lett. 2013, 102, 011111. [CrossRef]

141. Davis, R.; Rice, R.; Ballato, A.; Hawkins, T.; Foy, P.; Ballato, J. Toward a Photoconducting Semiconductor RF Fiber Antenna Array. Appl. Opt. 2010, 49, 5163-5168. [CrossRef] [PubMed]

142. He, R.; Day, T.; Krishnamurthi, M.; Sparks, J.; Sazio, P.; Gopalan, V.; Badding, J. Silicon p-i-n Junction Fibers. Adv. Mater. 2013, 25, 1461-1467. [CrossRef] [PubMed]

143. Homa, D.; Cito, A.; Pickrell, G.; Hill, C.; Scott, B. Silicon fiber with p-n junction. Appl. Phys. Lett. 2014, 105, 122110. [CrossRef]

144. He, R.; Sazio, P.; Peacock, A.; Healy, N.; Sparks, J.; Krishnamurthi, M.; Gopalan, V.; Badding, J. Integration of Gigahertz-bandwidth semiconductor devices inside microstructured optical fibers. Nat. Photonics 2012, 6, 174-179. [CrossRef]

145. Martinsen, F.; Smeltzer, B.; Nord, M.; Hawkins, T.; Ballato, J.; Gibson, U. Silicon-core glass fibres as microwire radial-junction solar cells. Sci. Rep. 2014, 4, 6283. [CrossRef] [PubMed]

146. Martinsen, F.; Ballato, J.; Hawkins, T.; Gibson, U. Bulk fabrication and properties of solar grade silicon microwires. Appl. Phys. Lett. Mater. 2014, 2, 116108. [CrossRef]

147. Martinsen, F.; Smeltzer, B.; Ballato, J.; Hawkins, T.; Jones, M.; Gibson, U. Light trapping in horizontally aligned silicon microwire solar cells. Opt. Express. 2015, 23, A1463-A1471. [CrossRef] [PubMed]

148. Savage, J.A. Optical properties of chalcogenide glasses. J. Non-Cryst. Solids 1982, 47, 101-116. [CrossRef]

149. Snopatin, G.; Shiryaev, V.; Plotnichenko, V.; Dianov, E.; Churbanov, M. High-purity chalcogenide glasses for fiber optics. Inorg. Mater. 2009, 45, 1439-1460. [CrossRef]

150. Churbanov, M.F. High-purity chalcogenide glasses as materials for fiber optics. J. Non-Cryst. Solids 1995, 184, 25-29. [CrossRef]

151. Cui, S.; Boussard-Plédel, C.; Lucas, J.; Bureau, B. Te-based glass fiber for far-infrared biochemical sensing up to $16 \mu \mathrm{m}$. Opt. Express 2014, 22, 21253-21262. [CrossRef] [PubMed]

152. King, W.A.; Clare, A.G.; Lacourse, W.C. Laboratory preparation of highly pure $\mathrm{As}_{2} \mathrm{Se}_{3}$ glass. J. Non-Cryst. Solids 1995, 181, 231-237. [CrossRef]

153. Kokorina, V.F. Glasses for Infrared Optics; CRC Press: Boca Raton, FL, USA, 1996.

154. Hocdé, S.; Boussard-Plédel, C.; Fonteneau, G.; Lucas, J. Chalcogens based glasses for IR fiber chemical sensors. Solid State Sci. 2001, 3, 279-284. [CrossRef]

155. Danto, S.; Thompson, D.; Wachtel, P.; Musgraves, J.D.; Richardson, K.; Giroire, B. A comparative study of purification routes for $\mathrm{As}_{2} \mathrm{Se}_{3}$ chalcogenide glass. Int. J Appl. Glass Sci. 2013, 4, 31-41. [CrossRef]

156. Troles, J.; Coulombier, Q.; Canat, G.; Duhant, M.; Renard, W.; Toupin, P.; Calvez, L.; Renversez, G.; Smektala, F.; El Amraoui, M.; et al. Low loss microstructured chalcogenide fibers for large non linear effects at $1995 \mathrm{~nm}$. Opt. Express 2010, 18, 26647-26654. [CrossRef] [PubMed]

157. Mochalov, L.A.; Lobanov, A.S.; Nezhdanov, A.V.; Kostrov, A.V.; Vorotyntsev, V.M. Preparation of Ge-S-I and Ge-Sb-S-I glasses by plasma-enhanced chemical vapor deposition. J. Non-Cryst. Solids 2015, 423, 76-80. [CrossRef]

158. Churbanov, M.F.; Shiryaev, V.S.; Scripachev, I.V.; Snopatin, G.E.; Gerasimenko, V.V.; Smetanin, S.V.; Fadin, I.E.; Plotnichenko, V.G. Optical fibers based on As-S-Se glass system. J. Non-Cryst. Solids 2001, 284, 146-152. [CrossRef] 
159. Kim, W.H.; Nguyen, V.Q.; Shaw, L.B.; Busse, L.E.; Florea, C.; Gibson, D.J.; Gattass, R.R.; Bayya, S.S.; Kung, F.H.; Chin, G.D.; et al. Recent progress in chalcogenide fiber technology at NRL. J. Non-Cryst. Solids 2016, 431, 8-15. [CrossRef]

160. Kobelke, J.; Kirchhof, J.; Scheffler, M.; Schwuchow, A. Chalcogenide glass single mode fibres-Preparation and properties. J. Non-Cryst. Solids 1999, 257, 226-231. [CrossRef]

161. Chenard, F.; Alvarez, O.; Moawad, H. MIR chalcogenide fiber and devices. In Proceedings of the SPIE BiOS, International Society for Optics and Photonics, San Francisco, CA, USA, 2015; p. 93170B.

162. Lafond, C.; Couillard, J.-F.; Delarosbil, J.-L.; Sylvain, F.; de Sandro, P. Recent improvements on mid-IR chalcogenide optical fibers. In Proceedings of the SPIE Defense + Security, International Society for Optics and Photonics, Batimore, MD, USA, 2014; p. 90701C.

163. Houizot, P.; Smektala, F.; Couderc, V.; Troles, J.; Grossard, L. Selenide glass single mode optical fiber for nonlinear optics. Opt. Mater. 2007, 29, 651-656.

164. Troles, J.; Niu, Y.; Duverger-Arfuso, C.; Smektala, F.; Brilland, L.; Nazabal, V.; Moizan, V.; Desevedavy, F.; Houizot, P. Synthesis and characterization of chalcogenide glasses from the system Ga-Ge-Sb-S and preparation of a single-mode fiber at $1.55 \mu \mathrm{m}$. Mater. Res Bull. 2008, 43, 976-982. [CrossRef]

165. Conseil, C.; Coulombier, Q.; Boussard-Pledel, C.; Troles, J.; Brilland, L.; Renversez, G.; Mechin, D.; Bureau, B.; Adam, J.L.; Lucas, J. Chalcogenide step index and microstructured single mode fibers. J. Non-Cryst. Solids 2011, 357, 2480-2483. [CrossRef]

166. Savage, S.D.; Miller, C.A.; Furniss, D.; Seddon, A.B. Extrusion of chalcogenide glass preforms and drawing to multimode optical fibers. J. Non-Cryst. Solids 2008, 354, 3418-3427. [CrossRef]

167. Russell, P. Photonic crystal fibers. Science 2003, 299, 358-362. [CrossRef] [PubMed]

168. Birks, T.A.; Roberts, P.J.; Russell, P.S.J.; Atkin, D.M.; Shepherd, T.J. Full 2-D photonic bandgaps in silica/air structures. Electron. Lett. 1995, 31, 1941-1943. [CrossRef]

169. Monro, T.M.; West, Y.D.; Hewak, D.W.; Broderick, N.G.R.; Richardson, D.J. Chalcogenide holey fibres. Electron. Lett. 2000, 36, 1998-2000. [CrossRef]

170. Brilland, L.; Smektala, F.; Renversez, G.; Chartier, T.; Troles, J.; Nguyen, T.N.; Traynor, N.; Monteville, A. Fabrication of complex structures of holey fibers in chalcogenide glass. Opt. Express 2006, 14, 1280-1285. [CrossRef] [PubMed]

171. Birks, T.A.; Knight, J.C.; Russell, P.S. Endlessly single-mode photonic crystal fiber. Opt. Lett. 1997, 22, 961-963. [CrossRef] [PubMed]

172. Renversez, G.; Bordas, F.; Kuhlmey, B.T. Second mode transition in microstructured optical fibers: Determination of the critical geometrical parameter and study of the matrix refractive index and effects of cladding size. Opt. Lett. 2005, 30, 1264-1266. [CrossRef] [PubMed]

173. Toupin, P.; Brilland, L.; Boussard-Pledel, C.; Bureau, B.; Mechin, D.; Adam, J.-L.; Troles, J. Comparison between chalcogenide glass single index and microstructured exposed-core fibers for chemical sensing. J. Non-Cryst. Solids 2013, 377, 217-219. [CrossRef]

174. Gattass, R.R.; Rhonehouse, D.; Gibson, D.; McClain, C.C.; Thapa, R.; Nguyen, V.Q.; Bayya, S.S.; Weiblen, R.J.; Menyuk, C.R.; Shaw, L.B.; et al. Infrared glass-based negative-curvature anti-resonant fibers fabricated through extrusion. Opt. Express 2016, 24, 25697-25703. [CrossRef] [PubMed]

175. Coulombier, Q.; Brilland, L.; Houizot, P.; Chartier, T.; Nguyen, T.N.; Smektala, F.; Renversez, G.; Monteville, A.; Méchin, D.; Pain, T.; et al. Casting method for producing low-loss chalcogenide microstructured optical fibers. Opt. Express 2010, 18, 9107-9112. [CrossRef] [PubMed]

176. El-Amraoui, M.; Gadret, G.; Jules, J.C.; Fatome, J.; Fortier, C.; Désévédavy, F.; Skripatchev, I.; Messaddeq, Y.; Troles, J.; Brilland, L.; et al. Microstructured chalcogenide optical fibers from $\mathrm{As}_{2} \mathrm{~S}_{3}$ glass: Towards new IR broadband sources. Opt. Express 2010, 18, 26655-26665. [CrossRef] [PubMed]

177. Zhang, P.; Zhang, J.; Yang, P.; Dai, S.; Wang, X.; Zhang, W. Fabrication of chalcogenide glass photonic crystal fibers with mechanical drilling. Opt. Fiber Technol. 2015, 26 Pt B, 176-179. [CrossRef]

178. Heo, J.; Rodrigues, M.; Saggese, S.J.; Sigel, G.H. Remote fiber-optic chemical sensing using evanescent-wave interactions in chalcogenide glass fibers. Appl. Opt. 1991, 30, 3944-3951. [CrossRef] [PubMed]

179. Keirsse, J.; Boussard-Pledel, C.; Loreal, O.; Sire, O.; Bureau, B.; Leroyer, P.; Turlin, B.; Lucas, J. IR optical fiber sensor for biomedical applications. Vib. Spectrosc. 2003, 32, 23-32. [CrossRef] 
180. Charpentier, F.; Troles, J.; Coulombier, Q.; Brilland, L.; Houizot, P.; Smektala, F.; Boussard-Pledel, C.; Nazabal, V.; Thibaud, N.; Le Pierres, K.; et al. $\mathrm{CO}_{2}$ detection using microstructured chalcogenide fibers. Sens. Lett. 2009, 7, 745-749. [CrossRef]

181. Wilhelm, A.A.; Lucas, P.; DeRosa, D.L.; Riley, M.R. Biocompatibility of Te-As-Se glass fibers for cell-based bio-optic infrared sensor. J. Mater. Res. 2007, 22, 1098-1104. [CrossRef]

182. Lucas, P.; Wilhelm, A.A.; Videa, M.; Boussard-Plédel, C.; Bureau, B. Hemical stability of chalcogenide infrared glass fibers. Corros. Sci. 2008, 50, 2047-2052. [CrossRef]

183. Godard, A. Infrared (2-12 $\mu \mathrm{m})$ solid-state laser sources: A review. C. R. Phys. 2007, 8, 1100-1128. [CrossRef]

184. Xia, C.; Kumar, M.; Cheng, M.-Y.; Hegde, R.S.; Islam, M.N.; Galvanauskas, A.; Winful, H.G.; Terry, J.F.L.; Freeman, M.J.; Poulain, M.; et al. Power scalable mid-infrared supercontinuum generation in ZBLAN fluoride fibers with up to 1.3 watts time-averaged power. Opt. Express 2007, 15, 865-871. [CrossRef] [PubMed]

185. Heo, J. Optical characteristics of rare-earth doped sulfide glasses. J. Mater. Sci. Lett. 1995, 14, $1014-1016$. [CrossRef]

186. Park, B.J.; Seo, H.S.; Ahn, J.T.; Choi, Y.G.; Jeon, D.Y.; Chung, W.J. Mid-infrared (3.5-5.5 $\mu \mathrm{m})$ spectroscopic properties of $\mathrm{Pr}^{3+}$-doped Ge-Ga-Sb-Se glasses and optical fibers. J. Lumin. 2008, 128, 1617-1622. [CrossRef]

187. Shaw, L.B.; Cole, B.; Thielen, P.A.; Sanghera, J.S.; Aggarwal, I.D. Mid-wave IR and long-wave IR laser potential of rare-earth doped chalcogenide glass fiber. IEEE J. Quantum Elect. 2001, 37, 1127-1137. [CrossRef]

188. Schweizer, T.; Hewak, D.W.; Samson, B.N.; Payne, D.N. Spectroscopy of potential mid-infrared laser transitions in gallium lanthanum sulfide glass. J Lumin. 1997, 72-74, 419-421. [CrossRef]

189. Prudenzano, F.; Mescia, L.; Allegretti, L.A.; De Sario, M.; Palmisano, T.; Smektala, F.; Moizan, V.; Nazabal, V.; Troles, J. Design of $\mathrm{Er}^{3+}$-doped chalcogenide glass laser for mid-IR application. J. Non-Cryst. Solids 2009, 355, 1145-1148. [CrossRef]

190. Starecki, F.; Charpentier, F.; Doualan, J.-L.; Quetel, L.; Michel, K.; Chahal, R.; Troles, J.; Bureau, B.; Braud, A.; Camy, P. Mid-IR optical sensor for $\mathrm{CO}_{2}$ detection based on fluorescence absorbance of $\mathrm{Dy}^{3+}: \mathrm{Ga}_{5} \mathrm{Ge}_{20} \mathrm{Sb}_{10} \mathrm{~S}_{65}$ fibers. Sens. Actuators B Chem. 2015, 207, 518-525. [CrossRef]

191. Dudley, J.M.; Taylor, J.R. Supercontinuum Generation in Optical Fibers; Cambridge University Press: Cambridge, UK, 2010.

192. Petersen, C.R.; Møller, U.; Kubat, I.; Zhou, B.; Dupont, S.; Ramsay, J.; Benson, T.; Sujecki, S.; Abdel-Moneim, N.; Tang, Z.; et al. Mid-infrared supercontinuum covering the 1.4-13.3 $\mu \mathrm{m}$ molecular fingerprint region using ultra-high NA chalcogenide step-index fibre. Nat. Photonics 2014, 8, 830-834. [CrossRef]

193. Gattas, R.; Shaw, B.; Nguyen, V.Q.; Pureza, P.C.; Aggarwal, I.D.; Sanghera, J.S. All-fiber chalcogenide-bsed mid-infrared supercontinuum source. Opt. Fiber Technol. 2012, 18, 345-348. [CrossRef]

194. Mouawad, O.; Picot-Clemente, J.; Amrani, F.; Strutynski, C.; Fatome, J.; Kibler, B.; Desevedavy, F.; Gadret, G.; Jules, J.C.; Deng, D.; et al. Multioctave midinfrared supercontinuum generation in suspended-core chalcogenide fibers. Opt. Lett. 2014, 39, 2684-2687. [CrossRef] [PubMed]

195. Yu, Y.; Zhang, B.; Gai, X.; Zhai, C.; Qi, S.; Guo, W.; Yang, Z.; Wang, R.; Choi, D.-Y.; Madden, S.; et al. 1.8-10 mu $\mathrm{m}$ mid-infrared supercontinuum generated in a step-index chalcogenide fiber using low peak pump power. Opt. Lett. 2015, 40, 1081-1084. [CrossRef] [PubMed]

196. Møller, U.; Yu, Y.; Kubat, I.; Petersen, C.R.; Gai, X.; Brilland, L.; Méchin, D.; Caillaud, C.; Troles, J.; Luther-Davies, B.; et al. Multi-milliwatt mid-infrared supercontinuum generation in a suspended core chalcogenide fiber. Opt. Express 2015, 23, 3282-3291. [CrossRef] [PubMed]

197. Cheng, T.L.; Nagasaka, K.; Tuan, T.H.; Xue, X.J.; Matsumoto, M.; Tezuka, H.; Suzuki, T.; Ohishi, Y. Mid-infrared supercontinuum generation spanning 2.0 to $15.1 \mu \mathrm{m}$ in a chalcogenide step-index fiber. Opt. Lett. 2016, 41, 2117-2120. [CrossRef] [PubMed]

198. Zhang, B.; Yu, Y.; Zhai, C.; Qi, S.; Wang, Y.; Yang, A.; Gai, X.; Wang, R.; Yang, Z.; Luther-Davies, B. High brightness $2.2-12 \mu \mathrm{m}$ mid-infrared supercontinuum generation in a nontoxic chalcogenide step-index fiber. J. Am. Ceram. Soc. 2016, 99, 2565-2568. [CrossRef]

(C) 2017 by the authors. Licensee MDPI, Basel, Switzerland. This article is an open access article distributed under the terms and conditions of the Creative Commons Attribution (CC BY) license (http:/ / creativecommons.org/licenses/by/4.0/). 